\title{
Astronomical tunings of the Oligocene-Miocene transition from Pacific Ocean Site U1334 and implications for the carbon cycle
}

\author{
Helen M. Beddow ${ }^{1}$, Diederik Liebrand ${ }^{2,3}$, Douglas S. Wilson ${ }^{4}$, Frits J. Hilgen ${ }^{1}$, Appy Sluijs ${ }^{1}$, Bridget S. Wade ${ }^{5}$, and \\ Lucas J. Lourens ${ }^{1}$ \\ ${ }^{1}$ Department of Earth Sciences, Faculty of Geosciences, Utrecht University, Utrecht, the Netherlands \\ ${ }^{2}$ PalaeoClimate.Science, Utrecht (province), the Netherlands \\ ${ }^{3}$ MARUM - Center for Marine Environmental Science, University of Bremen, Bremen, Germany \\ ${ }^{4}$ Department of Earth Science, University of California, Santa Barbara, CA, USA \\ ${ }^{5}$ Department of Earth Sciences, Faculty of Mathematical and Physical Sciences, \\ University College London, Gower Street, London, UK
}

Correspondence: Diederik Liebrand (diederik@palaeoclimate.science)

Received: 20 October 2017 - Discussion started: 25 October 2017

Revised: 24 January 2018 - Accepted: 2 February 2018 - Published: 5 March 2018

\begin{abstract}
Astronomical tuning of sediment sequences requires both unambiguous cycle pattern recognition in climate proxy records and astronomical solutions, as well as independent information about the phase relationship between these two. Here we present two different astronomically tuned age models for the Oligocene-Miocene transition (OMT) from Integrated Ocean Drilling Program Site U1334 (equatorial Pacific Ocean) to assess the effect tuning has on astronomically calibrated ages and the geologic timescale. These alternative age models (roughly from $\sim 22$ to $\sim 24 \mathrm{Ma}$ ) are based on different tunings between proxy records and eccentricity: the first age model is based on an aligning $\mathrm{CaCO}_{3}$ weight (wt $\%$ ) to Earth's orbital eccentricity, and the second age model is based on a direct age calibration of benthic foraminiferal stable carbon isotope ratios $\left(\delta^{13} \mathrm{C}\right)$ to eccentricity. To independently test which tuned age model and associated tuning assumptions are in best agreement with independent ages based on tectonic plate-pair spreading rates, we assign the tuned ages to magnetostratigraphic reversals identified in deep-marine magnetic anomaly profiles. Subsequently, we compute tectonic plate-pair spreading rates based on the tuned ages. The resultant alternative spreading-rate histories indicate that the $\mathrm{CaCO}_{3}$ tuned age model is most consistent with a conservative assumption of constant, or linearly changing, spreading rates. The $\mathrm{CaCO}_{3}$ tuned age model thus provides robust ages and durations for polarity chrons C6Bn.1n-C7n.1r, which are not based on astronom-
\end{abstract}

ical tuning in the latest iteration of the geologic timescale. Furthermore, it provides independent evidence that the relatively large (several 10000 years) time lags documented in the benthic foraminiferal isotope records relative to orbital eccentricity constitute a real feature of the OligoceneMiocene climate system and carbon cycle. The age constraints from Site U1334 thus indicate that the delayed responses of the Oligocene-Miocene climate-cryosphere system and (marine) carbon cycle resulted from highly nonlinear feedbacks to astronomical forcing.

\section{Introduction}

Astronomically tuned age models are important in studies of Cenozoic climate change because they shed light on cause and effect relationships between insolation forcing and the linear and non-linear responses of Earth's climate system (e.g. Hilgen et al., 2012; Vandenberghe et al., 2012; Westerhold et al., 2017). As more Cenozoic paleoclimate records are generated that use astronomical tuning as the main highprecision dating tool, it is important to understand the assumptions and limitations inherent in this age calibration method, in particular with respect to assumptions related to phase relationships between tuning signal and target curves (i.e. climate proxy records and astronomical solutions, respectively). These phase assumptions have implications for 
(i) determining the absolute timing of events, (ii) the understanding of leads and lags in the climate system, and (iii) the exact astronomical frequencies that are present in climate proxy records after tuning.

Previously published astronomically tuned age models for high-resolution climate records that span the OligoceneMiocene transition (OMT, $\sim 23 \mathrm{Ma}$ ) have used different tuning signal curves for sites from different paleoceanographic settings. In addition, different tuning target curves have been applied. For example, records from Ocean Drilling Program (ODP) Sites 926 and 929 from the Ceara Rise (equatorial Atlantic) were tuned using magnetic susceptibility and/or colour reflectance records (i.e. proxies for bulk sediment carbonate content) as a tuning signal curve and used obliquity as the main tuning target curve, sometimes with weaker precession and eccentricity components added (e.g. Shackleton et al., 1999, 2000; Zachos et al., 2001; Pälike et al., 2006a). In contrast, sediments from ODP Site 1090 from the Agulhas Ridge (Atlantic sector of the Southern Ocean) and ODP Site 1218 from the equatorial Pacific Ocean were tuned using benthic foraminiferal stable oxygen $\left(\delta^{18} \mathrm{O}\right)$ and/or carbon $\left(\delta^{13} \mathrm{C}\right)$ isotope records as a tuning signal (e.g. Billups et al., 2004; Pälike et al., 2006b). These records used different combinations of eccentricity, obliquity, and/or precession as tuning targets (ETP curves).

More recently, Oligocene-Miocene records from ODP Site 1264 and middle Miocene records from Integrated Ocean Drilling Program (IODP) Site U1335 used the Earth's eccentricity solution as the sole tuning target. These studies used lithological data, such as elemental estimates based on $\mathrm{X}$-ray fluorescence (XRF) core scanning records, as the sole tuning signal. The records from both these sites are characterized by a clear expression of eccentricity, either resulting from productivity-dominated cycles (at Site 1264; Liebrand et al., 2016) or dissolution-dominated cycles (at Site U1335; Kochhann et al., 2016). The general phase relationships between the $\sim 110 \mathrm{kyr}$ cycles and $405 \mathrm{kyr}$ cycles (in the case of Site U1335) in lithologic records and the stable eccentricity solution for this interval (Laskar et al., 2011a, b), i.e. whether maxima in signal curve correspond to minima or maxima in the target curve, were straightforward to derive (Liebrand et al., 2016; Kochhann et al., 2016). These broadscale phase relationships were in agreement with those previously derived using benthic foraminiferal $\delta^{18} \mathrm{O}$ and $\delta^{13} \mathrm{C}$ records (e.g. Zachos et al., 2001; Pälike et al., 2006b).

The different options for astronomical age calibration of the Oligocene-Miocene time interval has resulted in large variations in the precise phase estimates after tuning between $\sim 110 \mathrm{kyr}$ and $405 \mathrm{kyr}$ cycles present in both the eccentricity solution and in lithologic and climatologic proxy records. In addition, the choice of tuning signal curve may result in different cyclostratigraphic interpretations and different ages and durations of geologic events. To obtain better constraints for the true phase relationships of the $\sim 110$ and $405 \mathrm{kyr}$ cycles between benthic foraminiferal stable isotope records and orbital eccentricity, and to better understand the implications that initial phase assumptions for astronomical age calibration have on absolute ages across the OMT, we need independent dates that are free from tuning phase assumptions. Previous studies have successfully used plate-pair spreading rates to date magnetochron reversals and used these ages as an independent age control (e.g. Hilgen et al., 1991a, b; Wilson, 1993; Lourens et al., 2004).

Here, we present two astronomically tuned age models for newly presented (estimates of) sediment $\mathrm{CaCO}_{3}$ content and previously published high-resolution benthic foraminiferal $\delta^{18} \mathrm{O}$ and $\delta^{13} \mathrm{C}$ records across the OMT from IODP Site U1334 (eastern equatorial Pacific Ocean; Beddow et al., 2016). We select the sediment $\mathrm{CaCO}_{3}$ content and benthic foraminiferal $\delta^{13} \mathrm{C}$ as tuning signals because these data are generally thought to represent two end-members in terms of tuning phase assumptions (Pälike et al., 2006a, b; Liebrand et al., 2016). We evaluate the implications of using these different tuning proxies for (i) absolute ages of magnetochron reversals and (ii) the leads and lags between the eccentricity tuning target and lithologic-paleoclimate tuning signals. We achieve this by computing the spreading-rate histories of a suite of tectonic plate pairs, after assigning the astronomically tuned ages to the magnetostratigraphic reversals in their anomaly profiles. The constraints given by the long-term evolutions of these alternative spreading-rate histories are sufficiently precise to discriminate between tuning options and phase assumptions.

\section{Materials and methods}

\subsection{Site description}

Site U1334, located in the eastern equatorial Pacific (4794 mb.s.l.; $7^{\circ} 59.998^{\prime} \mathrm{N}, 131^{\circ} 58.408^{\prime} \mathrm{W}$ ), was recovered during IODP Expedition 320 (Fig. 1). Upper Oligocene and lower Miocene sediments from Site U1334 were deposited at a paleodepth of $\sim 4200 \mathrm{mb}$.s.l. and consist of foraminiferand radiolaria-bearing nannofossil ooze and chalk (Pälike et al., 2010, 2012). An expanded Oligocene-Miocene section with a well-defined magnetostratigraphy was recovered (Pälike et al., 2010; Channell et al., 2013), and a continuous spliced record of Holes A, B, and C was placed on a core composite depth scale below the sea floor (CCSF-A; equivalent to metres composite depth; Figs. 2 and 3; Westerhold et al., 2012a). Samples were taken along the splice and all results presented here follow this depth model (Beddow et al., 2016).

\subsection{Coulometric $\mathrm{CaCO}_{3}$ and magnetic susceptibility}

Lithological records from Site U1334 that span the OMT show large variability in $\mathrm{CaCO}_{3}$ content (Pälike et al., 2010). To obtain a high-resolution and continuous lithological proxy record, we estimate the $\mathrm{CaCO}_{3}$ wt\% of 


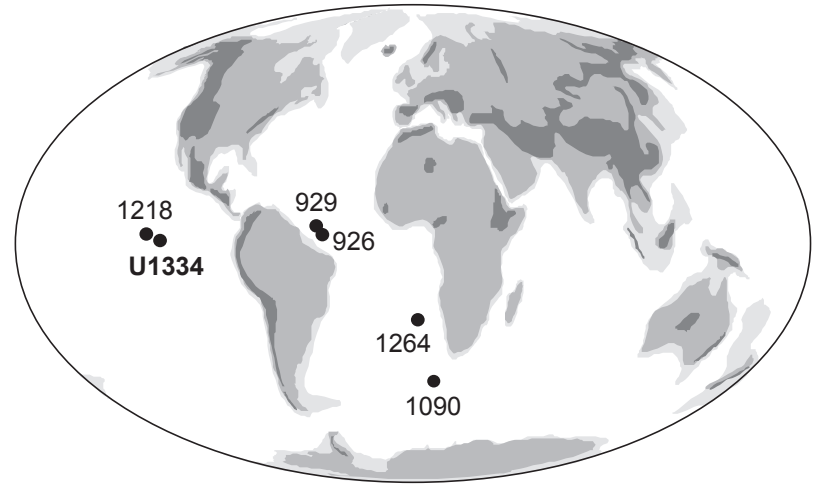

Figure 1. Locations of ODP and IODP drill sites discussed in this study. Location of IODP Site U1334 with reference to ODP Sites $1264,1218,926,929$, and 1090.

the dry sediment (hereafter $\mathrm{CaCO}_{3}$ content) by calibrating high-resolution shipboard magnetic susceptibility data (MS) to lower-resolution discrete shipboard coulometric $\mathrm{CaCO}_{3}$ measurements for Site U1334 (Pälike et al., 2010). Minimum MS values correspond to maximum $\mathrm{CaCO}_{3}$ values. The correlation between coulometric $\mathrm{CaCO}_{3}$ measurements and MS was calculated using a linear regression line, with an $R^{2}$ value of 0.92 (Fig. 2), indicating that $\sim 90 \%$ of the variability in the MS record is caused by changes in the bulk sediment $\mathrm{CaCO}_{3}$ content. Middle Miocene $\mathrm{CaCO}_{3}$ records from nearby Site U1335 show negatively skewed cycle shapes and have been interpreted as a dissolution-dominated signal (Herbert, 1994; Kochhann et al., 2016). In contrast, cycle shapes in the $\mathrm{CaCO}_{3}$ content record for the Oligocene-Miocene of Site $\mathrm{U} 1334$ are less skewed, suggesting that here $\mathrm{CaCO}_{3}$ content was predominantly controlled by a combination of productivity and dissolution.

\subsection{Benthic foraminiferal stable isotope records and magnetostratigraphic age model}

We use the benthic foraminiferal $\delta^{18} \mathrm{O}$ and $\delta^{13} \mathrm{C}$ records of Site U1334, which were measured on the Oridorsalis umbonatus and Cibicides mundulus benthic foraminifer species (Beddow et al., 2016). To construct this mixed-species record, $O$. umbonatus values were corrected to $C$. mundulus values based on ordinary least squares linear regression that was based on an analysis of 180 pairs of inter-species isotope values to which a comparison was applied (for details, see Beddow et al., 2016). The benthic foraminiferal stable isotope datasets at Site U1334 were placed on a magnetostratigraphic age model calculated by fitting a third-order polynomial through 14 magnetostratigraphic age-depth tie points. Twelve of these chron boundaries fall within the study interval, are given in Table 1, and are shown in Figs. 3 and 4. This magnetostratigraphic age model yields an initial time period from $\sim 21.9$ to $24.1 \mathrm{Ma}$ for the study interval (Fig. 4; Channell et al., 2013; Beddow et al., 2016).

\subsection{Spectral analysis}

We use the statistical software programme AnalySeries (Paillard et al., 1996) to conduct spectral analyses on the benthic foraminiferal $\delta^{13} \mathrm{C}$ and $\delta^{18} \mathrm{O}$ and the $\mathrm{CaCO}_{3}$ datasets in the depth domain on the magnetostratigraphic age model (Beddow et al., 2016) and on both astronomically tuned age model options presented here. Prior to analysis, the $\mathrm{CaCO}_{3}$ content and stable isotope data were resampled at 2 and $5 \mathrm{~cm}$ in the depth domain and at 2.5 and $3.0 \mathrm{kyr}$ in the age domain, respectively, and trends longer than $6 \mathrm{~m}$, or $600 \mathrm{kyr}$, were removed using a notch filter (Paillard et al., 1996). Blackman-Tukey spectral analysis was used to identify dominant periodicities present within the data, which subsequently were filtered using Gaussian filters. We applied cross-spectral analysis to identify coherency and phase relationships between the eccentricity and the $\mathrm{CaCO}_{3}, \delta^{18} \mathrm{O}$, and $\delta^{13} \mathrm{C}$ chronologies. These calculations were performed at $95 \%$ significance. Evolutive spectral analyses using a sliding fast Fourier transform (FFT) were computed using MATLAB.

\subsection{Reversal ages based on plate-pair spreading rates}

We use previously published magnetic anomaly profiles of tectonic plate-pair spreading rates (Wilson, 1993) to independently test the astronomical age models for Site U1334. This age comparison method is similar to that previously used to support astronomically tuned age models for the Miocene, Pliocene, and Pleistocene (Hilgen et al., 1991a, b; Krijgsman et al., 1999; Hüsing et al., 2007). We have selected plate pairs with high-quality anomaly profiles and relatively high spreading rates. These plate pairs are in order of decreasing spreading rate: Pacific-Nazca, Pacific-Juan de Fuca, Australia-Antarctic, and Pacific-Antarctic. Data for the Pacific-Nazca pair are limited to the northern part of the system, which is well surveyed from studies of the separation of the Cocos plate from the northern Nazca plate during chron C6Bn (Lonsdale, 2005; Barckhausen et al., 2008). Pacific-Juan de Fuca data are from immediately north of the Mendocino fracture zone. Reversal ages based on these spreading rates are also used in previous timescale calibrations (e.g. Cande and Kent, 1992) despite the fact that for the Oligocene-Miocene time interval only the Pacific plate record has survived and the Juan de Fuca plate was subducted. Wilson (1988) interpreted a sudden change in spreading-rate gradient for this pair from the south faster prior to $\mathrm{C} 6 \mathrm{Cn} .2 \mathrm{n}(\mathrm{o})$ to the north faster after that reversal. The dataset for the Australia-Antarctic pair is similar to that presented by Cande and Stock (2004). It is expanded from that used by Lourens et al. (2004), who assigned reversal ages spanning from 18.524 to $23.030 \mathrm{Ma}$ for the chron interval 


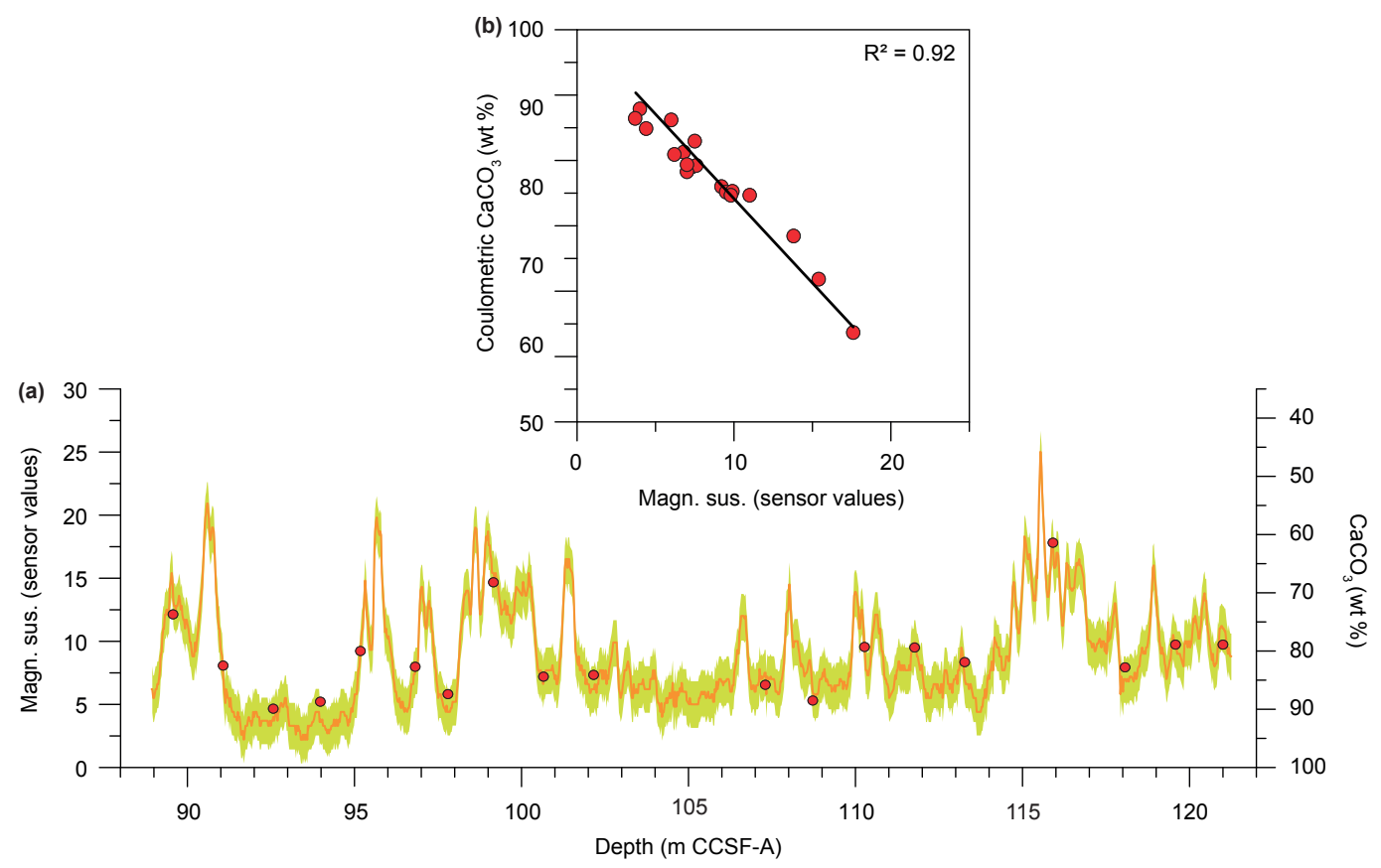

Figure 2. Calibration between the shipboard magnetic susceptibility record and shipboard coulometric $\mathrm{CaCO}_{3}$ measurements to estimate $\mathrm{CaCO}_{3}$ content. (a) The magnetic susceptibility and $\mathrm{CaCO}_{3}$ content record (Pälike et al., 2010; Westerhold et al., 2012a). Green area indicates the $2 \sigma$ uncertainty estimate of the coulometry measurements (Pälike et al., 2010). Red circles represent shipboard coulometric $\mathrm{CaCO}_{3}$ values. (b) The relationship between coulometric $\mathrm{CaCO}_{3}$ measurements and resampled magnetic susceptibility is calculated using ordinary least squares linear regression and yields an $R^{2}$ value of 0.92 .

from $\mathrm{C} 5 \mathrm{Er}$ (top) to $\mathrm{C} 6 \mathrm{Cn} .2 \mathrm{n}$ (base) based on a linear interpolation of spreading rates of $69.9 \mathrm{~mm} \mathrm{yr}^{-1}$ for this plate pair. Data for Pacific-Antarctic come primarily from more recent surveys near the Menard and Vacquier fracture zones (Croon et al., 2008).

\section{Results}

\subsection{Lithologic and paleoclimatic records}

The synthetic wt $\%$ calcium carbonate record $\left(\mathrm{CaCO}_{3}\right.$ content wt $\%$ ) ranges between $\sim 45$ and $95 \%$, which is consistent with the coulometric $\mathrm{CaCO}_{3}$ wt $\%$ measurements on discrete samples (Figs. 2 and 3). Variability is generally twice as large in the lower Miocene section of the record, between 88.95 and $\sim 102 \mathrm{~m}$ CCSF-A (core composite depth below the sea floor), varying by $\sim 40 \%$ with several minima in the record dipping below $70 \%$ (Fig. 3). There is little variability in $\mathrm{CaCO}_{3}$ content across the OMT between $\sim 102$ and $\sim 106 \mathrm{~m}$ CCSF-A. The benthic foraminiferal $\delta^{18} \mathrm{O}$ record captures a large, partially transient shift towards more positive values at the Oligocene-Miocene boundary, with maximum values of $\sim 2.4 \%$ occurring at 104.5 CCSF-A (Fig. 3). After the boundary, both $\delta^{18} \mathrm{O}$ and $\delta^{13} \mathrm{C}$ values show higher-amplitude variability and more permanent shifts towards higher values (Beddow et al., 2016).

\subsection{Spectral analysis in the depth domain}

The power spectra of the $\mathrm{CaCO}_{3}$ content record in the depth domain reveal strong spectral peaks at frequencies of 0.20 and 0.65 cycles $^{-1}$ (Fig. 3). These frequencies broadly correspond to those found in the benthic foraminiferal $\delta^{18} \mathrm{O}$ and $\delta^{13} \mathrm{C}$ depth series at 0.15 and 0.65 cycles m$^{-1}$ (Beddow et al., 2016). High-amplitude cycles with frequencies in the range between $\sim 0.20$ and 0.80 cycles $\mathrm{m}^{-1}$ are present in all datasets with an approximate $1: 4$ ratio, suggesting a strong influence of eccentricity on the records (i.e. $\sim 110: 405 \mathrm{kyr}$ cycles). This interpretation of strong eccentricity is supported by the application of the initial magnetostratigraphic age model (Beddow et al., 2016).

\section{Astronomical tunings of Site U1334}

\subsection{Initial age model}

As a starting point for astronomical tuning we use an initial magnetostratigraphic age model (Beddow et al., 2016; Channel et al., 2013), which is based on the chron reversal ages of the 2012 geologic timescale (GTS2012; Vandenberghe et al., 2012; Hilgen et al., 2012; see Table 1, Fig. 4). On this initial age model, (time-evolutive) power spectra demonstrate that the $\mathrm{CaCO}_{3}$ content and benthic foraminiferal $\delta^{18} \mathrm{O}$ and $\delta^{13} \mathrm{C}$ records are dominated by $\sim 110$ and $405 \mathrm{kyr}$ eccentricity- 

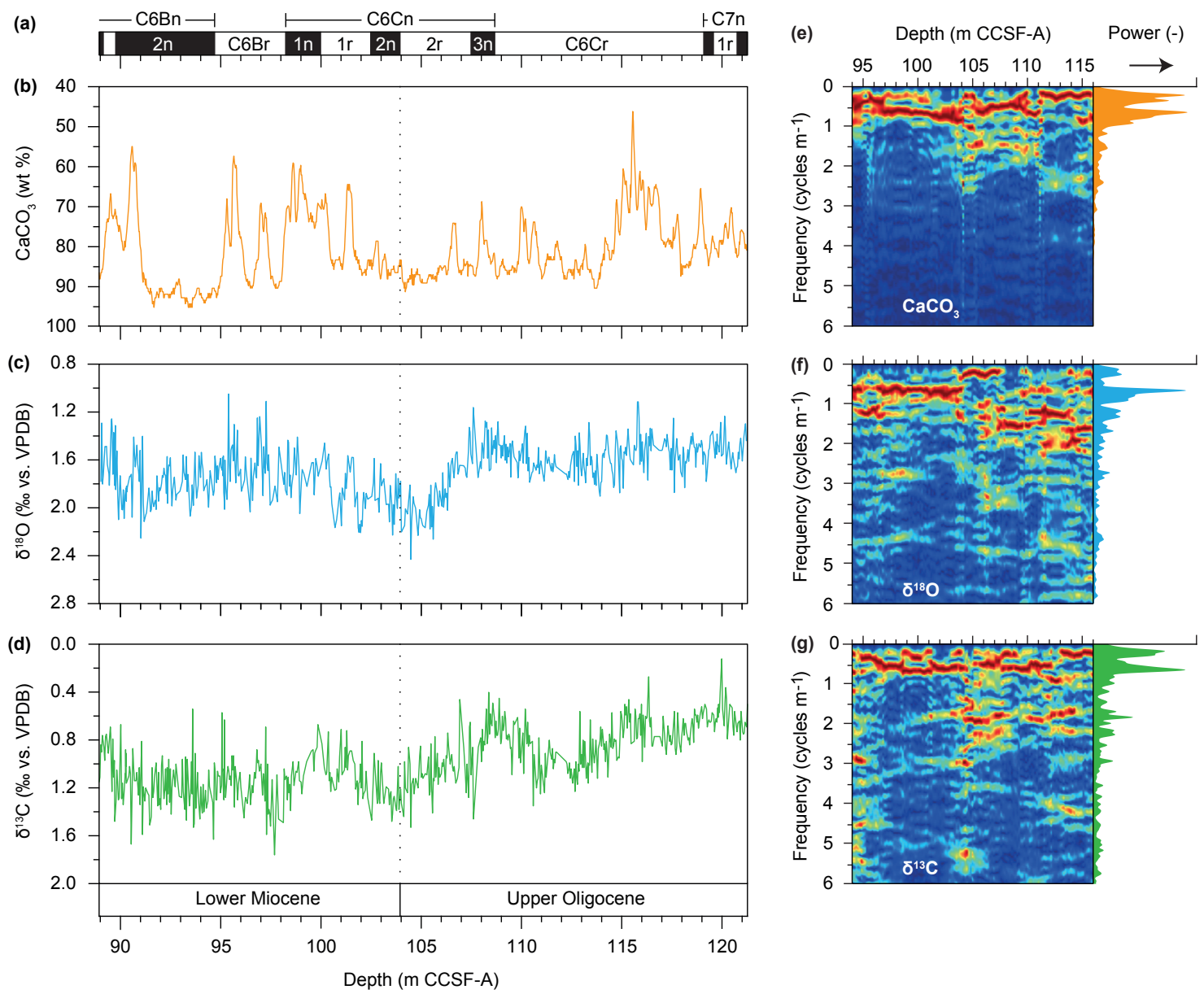

Figure 3. Site U1334 datasets, evolutive spectra, and power spectra against depth. (a) Magnetostratigraphy for Site U1334 (Channell et al., 2013). (b) The $\mathrm{CaCO}_{3}$ content record. (c) The benthic foraminiferal $\delta^{18} \mathrm{O}$ record. (d) The benthic foraminiferal $\delta^{13} \mathrm{C}$ record. Dashed line marks the base of magnetochron C6Cn.2n, the boundary between the Oligocene and the Miocene. (e) Depth-evolutive FFT analysis and power spectra of the $\mathrm{CaCO}_{3}$ content record, (f) the benthic foraminiferal $\delta^{18} \mathrm{O}$ record, and $(\mathrm{g})$ the benthic foraminiferal $\delta^{13} \mathrm{C}$ record. All data are presented on the revised splice of Westerhold et al. (2012a).

paced cycles, with short intervals of strong responses at higher frequencies (Fig. 5). To further assess the influence of eccentricity on the records from Site U1334, we filter the $\sim 110$ and $405 \mathrm{kyr}$ cycles of the $\mathrm{CaCO}_{3}$ content and $\delta^{13} \mathrm{C}$ records (Figs. 6a and 7a). In total, we observe just over five $405 \mathrm{kyr}$ cycles in both the filtered $\mathrm{CaCO}_{3}$ content and $\delta^{13} \mathrm{C}$ records. There is a notable difference in the number of filtered $\sim 110 \mathrm{kyr}$ cycles present between these two datasets. We observe 23 complete $\sim 110 \mathrm{kyr}$ cycles in the $\mathrm{CaCO}_{3}$ content record and 21 in the $\delta^{13} \mathrm{C}$ record. Visual assessment of the number of cycles is not always straightforward because not every $\sim 110 \mathrm{kyr}$ cycle is expressed equally strong in all data records. In the eccentricity solution for the interval approximately between 21.9 and $24.1 \mathrm{Ma}$, we count five and a half $405 \mathrm{kyr}$ cycles and 22 complete $\sim 110 \mathrm{kyr}$ cycles. These numbers are largely in agreement with those obtained from visual assessment and Gaussian filtering.

\subsection{Astronomical target curve}

For our astronomical target curve, we select Earth's orbital eccentricity. Time series analyses on the $\mathrm{CaCO}_{3}$ content and the benthic foraminiferal $\delta^{18} \mathrm{O}$ and $\delta^{13} \mathrm{C}$ records in the depth domain and on the initial age model indicate that eccentricity is the dominant cycle and that higher-frequency cycles are intermittently expressed (Fig. 5). Additional reasons to select eccentricity as the sole tuning target for the OMT of Site U1334 are the uncertain phase relationships of the data records to precession and the unknown evolution of tidal dissipation and dynamical ellipticity before $10 \mathrm{Ma}$ (Zeeden et al., 2014). These parameters affect the long-term stability of both the precession and obliquity solutions (Lourens et al., 2004; Husing et al., 2007). We use the most recent nominal eccentricity solution (i.e. La2011_ecc3L; Laskar et al., 2011a, b; Westerhold et al., 2012b) as a tuning target, and for the OMT interval this solution is not significantly dif- 
Table 1. Comparison of magnetostratigraphic reversal ages. Chron boundary ages across the Oligocene-Miocene transition from the published literature and this study. Age differences with the GTS2012 age are presented in the lower part of the table. A: Lourens et al. (2004); B: Hilgen et al. (2012); Vandenberghe et al. (2012); C: Billups et al. (2004); D and E: Pälike et al. (2006b); F: Liebrand et al. (2016); G: Channell et al. (2013); H and I: this study. For further Oligocene-Miocene age calibrations, see van Peer et al., 2017a, b and Egger et al., 2016.

\begin{tabular}{|c|c|c|c|c|c|c|c|c|c|}
\hline Chron & $\begin{array}{c}\text { A: age } \\
\text { GTS2004 } \\
\text { (Ma) }\end{array}$ & $\begin{array}{l}\text { B: age } \\
\text { GTS2012 } \\
\text { (Ma) }\end{array}$ & $\begin{array}{c}\text { C: } 1090 \text { tuned } \\
\text { age }(\mathrm{Ma})\end{array}$ & $\begin{array}{c}\text { D: } 1218 \\
\text { manual tuned } \\
\text { age }(\mathrm{Ma})\end{array}$ & $\begin{array}{c}\text { E: } 1218 \text { auto } \\
\text { tuned age } \\
(\mathrm{Ma})\end{array}$ & $\begin{array}{c}\mathrm{F}: 1264 \mathrm{mid} \\
\text { tuned age } \\
(\mathrm{Ma})\end{array}$ & $\begin{array}{c}\text { G: U1334 } \\
\text { depth CCSF-A } \\
\text { (m) }\end{array}$ & $\begin{array}{c}\mathrm{H}: \mathrm{U} 1334 \\
\mathrm{CaCO}_{3} \text { tuned } \\
\text { age (Ma) }\end{array}$ & $\begin{array}{c}\text { I: } \mathrm{U} 1334 \delta^{13} \mathrm{C} \\
\text { tuned age } \\
(\mathrm{Ma})\end{array}$ \\
\hline C6Bn.1n (o) & 21.936 & 21.936 & 21.991 & 22.010 & 21.998 & & 89.17 & 21.985 & 22.115 \\
\hline C6Bn.1r (o) & 21.992 & 21.992 & 22.034 & 22.056 & 22.062 & & 89.79 & 22.042 & 22.165 \\
\hline C6Bn.2n (o) & 22.268 & 22.268 & 22.291 & 22.318 & 22.299 & 22.300 & 94.72 & 22.342 & 22.473 \\
\hline $\mathrm{C} 6 \mathrm{Br}(\mathrm{o})$ & 22.564 & 22.564 & 22.593 & 22.595 & 22.588 & 22.608 & 98.26 & 22.621 & 22.697 \\
\hline C6Cn.1n (o) & 22.754 & 22.754 & 22.772 & 22.689 & 22.685 & 22.760 & 100.00 & 22.792 & 22.809 \\
\hline C6Cn.1r (o) & 22.902 & 22.902 & 22.931 & 22.852 & 22.854 & 22.944 & 102.50 & 22.973 & 22.970 \\
\hline C6Cn.2n (o) & 23.030 & 23.030 & 23.033 & 23.024 & 23.026 & 23.052 & 103.96 & 23.040 & 23.053 \\
\hline C6Cn.2r (o) & 23.249 & 23.233 & 23.237 & 23.233 & 23.278 & 23.247 & 107.50 & 23.212 & 23.211 \\
\hline C6Cn.3n (o) & 23.375 & 23.295 & 23.299 & 23.295 & 23.340 & 23.332 & 108.68 & 23.318 & 23.286 \\
\hline $\mathrm{C} 6 \mathrm{Cr}(\mathrm{o})$ & 24.044 & 23.962 & 23.988 & 23.962 & 24.022 & & 119.10 & 24.025 & 24.026 \\
\hline C7n. 1 n (o) & 24.102 & 24.000 & 24.013 & 24.000 & 24.062 & & 119.58 & 24.061 & 24.066 \\
\hline C7n.1r (o) & 24.163 & 24.109 & 24.138 & 24.109 & 24.147 & & 120.76 & 24.124 & 24.161 \\
\hline Chron & $\begin{array}{c}\Delta \mathrm{B}-\mathrm{C} \text { age } \\
(\mathrm{kyr})\end{array}$ & $\begin{array}{c}\Delta \mathrm{B}-\mathrm{D} \text { age } \\
(\mathrm{kyr})\end{array}$ & $\begin{array}{c}\Delta \mathrm{B}-\mathrm{E} \text { age } \\
(\mathrm{kyr})\end{array}$ & $\begin{array}{c}\Delta \mathrm{B}-\mathrm{F} \text { age } \\
(\mathrm{kyr})\end{array}$ & $\begin{array}{c}\Delta \mathrm{B}-\mathrm{H} \text { age } \\
(\mathrm{kyr})\end{array}$ & $\begin{array}{c}\Delta \mathrm{B}-\mathrm{I} \text { age } \\
(\mathrm{kyr})\end{array}$ & & & \\
\hline C6Bn.1n (o) & -55 & -74 & -62 & & -49 & -179 & & & \\
\hline C6Bn.1r (o) & -42 & -64 & -70 & & -50 & -173 & & & \\
\hline C6Bn.2n (o) & -23 & -50 & -31 & -32 & -74 & -205 & & & \\
\hline C6Br (o) & -29 & -31 & -24 & -44 & -57 & -133 & & & \\
\hline C6Cn.1n (o) & -18 & 65 & 69 & -6 & -38 & -55 & & & \\
\hline C6Cn.1r (o) & -29 & 50 & 48 & -42 & -71 & -68 & & & \\
\hline C6Cn.2n (o) & -3 & 6 & 4 & -22 & -10 & -23 & & & \\
\hline C6Cn.2r (o) & -4 & 0 & -45 & -14 & 21 & 22 & & & \\
\hline C6Cn.3n (o) & -4 & 0 & -45 & -37 & -23 & 9 & & & \\
\hline $\mathrm{C} 6 \mathrm{Cr}(\mathrm{o})$ & -26 & 0 & -60 & & -63 & -64 & & & \\
\hline C7n. $\ln (0)$ & -13 & 0 & -62 & & -61 & -66 & & & \\
\hline C7n.1r (o) & -29 & 0 & -38 & & -15 & -52 & & & \\
\hline
\end{tabular}

ferent from the La2004 eccentricity solution (Laskar et al., 2004), which was used to generate previous astronomically tuned high-resolution age models for this time interval (Pälike et al., 2006a, b).

\subsection{Astronomical age calibration of the OMT from Site U1334}

To test different ages and durations of the data from Site U1334 and the leads and lags of climate cycles with respect to eccentricity, we first consider the $\mathrm{CaCO}_{3}$ content record and then the benthic foraminiferal $\delta^{13} \mathrm{C}$ record as tuning signals. Both tuning options are underpinned by assumptions of a consistent and linear in-phase relationship between the tuning signal and the eccentricity target. Previously tuned climate records for the OMT have shown that these two datasets represent end-members with respect to phase assumptions, with $\mathrm{CaCO}_{3}$ content showing no lag or the smallest lag with respect to orbital eccentricity and with $\delta^{18} \mathrm{O}$ and $\delta^{13} \mathrm{C}$ showing increasingly larger lags to the $\sim 110$ and $405 \mathrm{kyr}$ eccentricity cycles (Liebrand et al., 2016; Pälike et al., 2006a, b). Thus, by selecting the $\mathrm{CaCO}_{3}$ content record and the benthic foraminiferal $\delta^{13} \mathrm{C}$ chronology, we span the full range of tuned ages that different phase assumptions between eccentricity and proxy data could possibly imply. We expect that the $\mathrm{CaCO}_{3}$ tuned age model is in best agreement with independent ages based on spreading rates, and hence that benthic foraminiferal $\delta^{13} \mathrm{C}$ will show the largest lag with respect to eccentricity.

\subsubsection{Astronomical tuning using the $\mathrm{CaCO}_{3}$ content record}

We use the initial magnetostratigraphic age model as a starting point for a more detailed $\sim 110 \mathrm{kyr}$ calibration of $\mathrm{CaCO}_{3}$ content of the sediment to eccentricity. $\mathrm{CaCO}_{3}$ maxima, mainly reflecting increased surface ocean productivity and/or decreased deep-ocean dissolution (e.g. Hodell et al., 2001), generally correspond to more positive $\delta^{18} \mathrm{O}$ values, which are indicative of cooler glacial periods. Hence, both bulk $\mathrm{CaCO}_{3}$ content and benthic foraminiferal $\delta^{18} \mathrm{O}$ values are linked to eccentricity minima and are therefore anti-correlated with eccentricity (Zachos et al., 2001; Pälike et al., 2006a, b). The $\mathrm{CaCO}_{3}$ content record is characterized by strong maxima, which we manually aligned to $\sim 110 \mathrm{kyr}$ eccentricity minima by visually selecting tie points (Fig. 6c). In addition to these well-expressed $\sim 110 \mathrm{kyr}$ cycles, we take the expression of the $405 \mathrm{kyr}$ cycle into account to establish the tuned age model. The data records from Site U1334 span the interval between 21.96 and 24.15 Ma (2.19 Myr duration) 


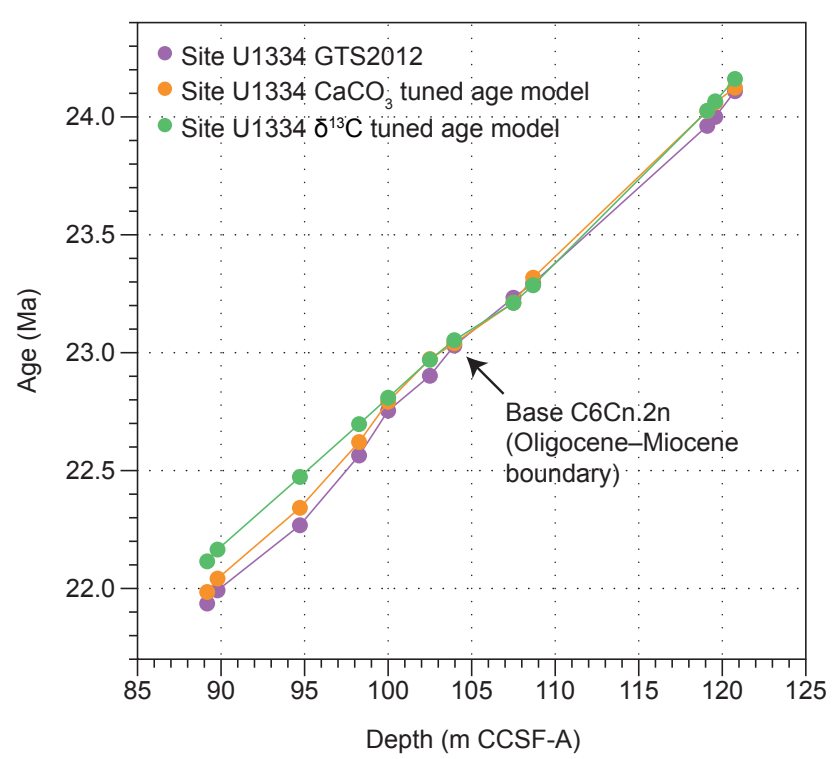

Figure 4. Depth vs. age relationships for the different age models for Site U1334. Magnetochron ages are based on GTS2012 (Vandenberghe et al., 2012; Hilgen et al., 2012), the initial age model (i.e. a third-order polynomial through the GTS2012 ages), the $\mathrm{CaCO}_{3}$ content age model, and the $\delta^{13} \mathrm{C}$ age model. Magnetochrons are plotted as coloured circles.

on the $\mathrm{CaCO}_{3}$ tuned age model. Linear sedimentation rates (LSRs) vary between 0.9 and $2.2 \mathrm{~cm} \mathrm{ky}^{-1}$ (Fig. 6). On average this yields a sample resolution of $3.6 \mathrm{kyr}$ for the benthic foraminiferal isotope records.

Evolutive analyses (i.e. FFT using a sliding window) of the $\mathrm{CaCO}_{3}$ content and benthic foraminiferal $\delta^{18} \mathrm{O}$ and $\delta^{13} \mathrm{C}$ records on the $\mathrm{CaCO}_{3}$ tuned age model indicate that the $405 \mathrm{kyr}$ cycle is relatively strongly expressed in all datasets (Fig. 5). However, this signal is weaker or absent across the OMT $(\sim 23 \mathrm{Ma})$ in the evolutive spectrum of $\mathrm{CaCO}_{3}$ content and post-OMT in benthic foraminiferal $\delta^{18} \mathrm{O}$. The $\sim 110 \mathrm{kyr}$ cycle is present in the data records on the $\mathrm{CaCO}_{3}$ tuned age model between 23.4 and $22.2 \mathrm{Ma}$ for $\mathrm{CaCO}_{3}$ content, between 23.0 and 22.2 for benthic foraminiferal $\delta^{18} \mathrm{O}$, and between 22.8 and 22.2 for benthic foraminiferal $\delta^{13} \mathrm{C}$. The $\sim 110 \mathrm{kyr}$ cycle is particularly pronounced in both the $\mathrm{CaCO}_{3}$ and the benthic foraminiferal $\delta^{18} \mathrm{O}$ records, and we can identify power at both the 125 and the $95 \mathrm{kyr}$ eccentricity cycles. We note that this could be a direct result from using eccentricity as a tuning target (see e.g. Shackleton et al., 1995; Huybers and Aharonson, 2010). For $\delta^{13} \mathrm{C}$, the evolutive analysis and power spectra indicate that the $\sim 110 \mathrm{kyr}$ cycle is more strongly expressed at the $125 \mathrm{kyr}$ periodicity compared to the $95 \mathrm{kyr}$ component. We find intermittent power present at a periodicity of $\sim 50 \mathrm{ky} \mathrm{cycle}^{-1}$, which is either related to the obliquity cycle that is offset towards a slightly longer periodicity or to the first harmonic of the $\sim 110$ kyr eccentricity cycle (King, 1996). The $\sim 50 \mathrm{kyr}$ cy- cle is best expressed in the benthic foraminiferal $\delta^{18} \mathrm{O}$ record on the $\mathrm{CaCO}_{3}$ tuned age model, in which we identify two main intervals with significant power at this periodicity, one between $\sim 23.5$ and $\sim 23.8 \mathrm{Ma}$ and the other between $\sim 22.4$ and $\sim 22.6 \mathrm{Ma}$ (Fig. 5).

Cross-spectral analyses between the $\mathrm{CaCO}_{3}$ content, $\delta^{18} \mathrm{O}$, and $\delta{ }^{13} \mathrm{C}$ records on the $\mathrm{CaCO}_{3}$ tuned age model and eccentricity indicate that all are significantly coherent at the 405,125 and 95 kyr eccentricity cycles (Fig. 5). Phase estimates of benthic foraminiferal $\delta^{18} \mathrm{O}$ with respect to eccentricity indicate a lag of $21 \pm 16 \mathrm{kyr}$ at the $405 \mathrm{kyr}$ period and $9 \pm 3 \mathrm{kyr}$ at the $\sim 110 \mathrm{kyr}$ periodicity (95\% confidence on error bars). The $\delta^{13} \mathrm{C}$ record lags eccentricity by $29 \pm 14 \mathrm{kyr}$ at the $405 \mathrm{kyr}$ cycle and by $9 \pm 4 \mathrm{kyr}$ at the $\sim 110 \mathrm{kyr}$ cycle (Fig. 5). The coherence between $\mathrm{CaCO}_{3}$ content and eccentricity is only just significant, and phase estimates are roughly in-phase with eccentricity: $6 \pm 24 \mathrm{kyr}$ at the $405 \mathrm{kyr}$ cycle and $-1 \pm 2 \mathrm{kyr}$ at the $\sim 110 \mathrm{kyr}$ cycle. These phase estimates between $\mathrm{CaCO}_{3}$ content and eccentricity are not surprising because $\mathrm{CaCO}_{3}$ content was used to obtain astronomically tuned ages. These phase relationships between $\mathrm{CaCO}_{3}$ and eccentricity thus confirm that the in-phase tuning assumption was applied successfully.

\subsubsection{Astronomical tuning using the benthic foraminiferal $\delta^{13} \mathrm{C}$ record}

An important consequence of the $\mathrm{CaCO}_{3}$ tuned age model is that eccentricity-related variability within the benthic foraminiferal $\delta^{13} \mathrm{C}$ record is not in-phase with eccentricity (Fig. 7b; Laurin et al., 2017). On both the initial magnetostratigraphic age model and on the $\mathrm{CaCO}_{3}$ tuned age model, the phase lag, as visually identified in the filtered records, between the $405 \mathrm{kyr}$ eccentricity cycle and the $405 \mathrm{kyr}$ cycle in $\delta^{13} \mathrm{C}$ increases during the early Miocene (Figs. 6 and 7). The $405 \mathrm{kyr}$ eccentricity pacing of $\delta^{13} \mathrm{C}$ is a consistent feature that characterizes the Cenozoic carbon cycle (Holbourn et al., 2004, 2013; Littler et al., 2014; Pälike et al., 2006a, b; Liebrand et al., 2016; Wade and Pälike, 2004), and to date no large changes in phase relationship have been documented. However, the increased phase lag in the response of the $405 \mathrm{kyr}$ cycle in $\delta^{13} \mathrm{C}$ to eccentricity, as is suggested by the $\mathrm{CaCO}_{3}$ tuned age model, could provide further support for a large-scale reorganization of the carbon cycle across the OMT as has previously been suggested based on a sudden increase in accumulation rates of benthic foraminifera and uranium-calcium values, suggesting increased organic carbon burial (Diester-Haas et al., 2011; Mawbey and Lear, 2013).

To test the validity of the large phase lag of the $405 \mathrm{kyr}$ cycle in benthic foraminiferal $\delta^{13} \mathrm{C}$ to eccentricity and to test the potential increase in this lag, we generate another astronomically tuned age model. This time, we use the benthic foraminiferal $\delta^{13} \mathrm{C}$ record as the tuning signal and assume that the $405 \mathrm{kyr}$ cycles and $\sim 110 \mathrm{kyr}$ cycles in benthic 


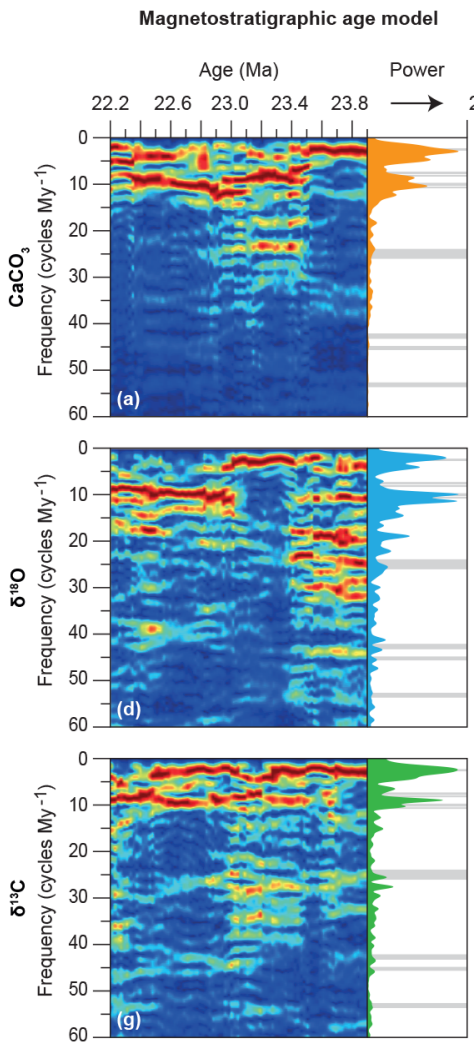

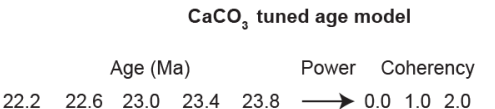
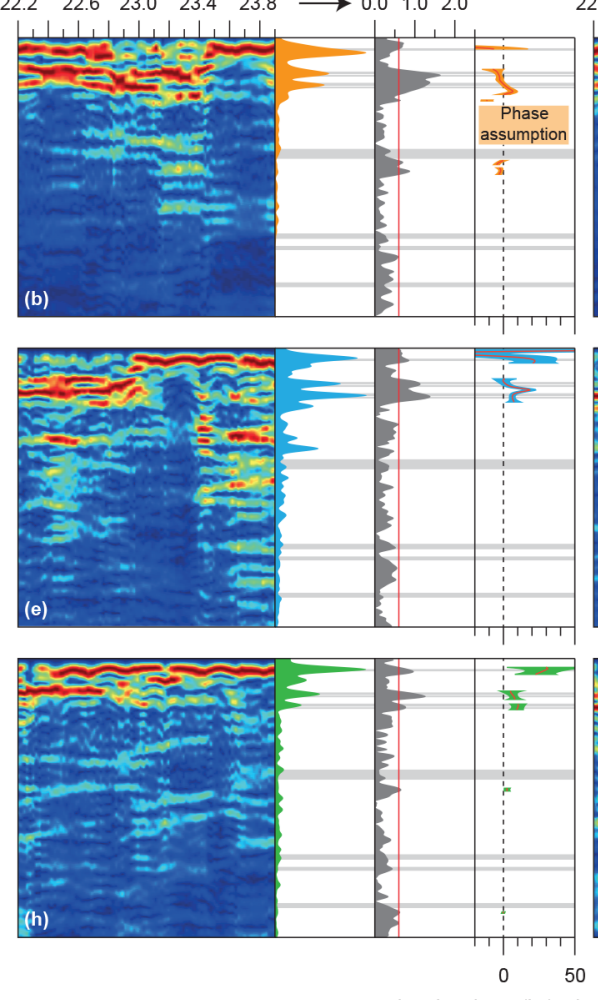

Lead $<$ phase $(k y)>$ lag

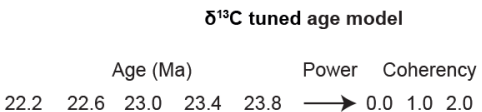

$22.2 \quad 22.6 \quad 23.0 \quad 23.4 \quad 23.8 \quad \longrightarrow 0.01 .02 .0$
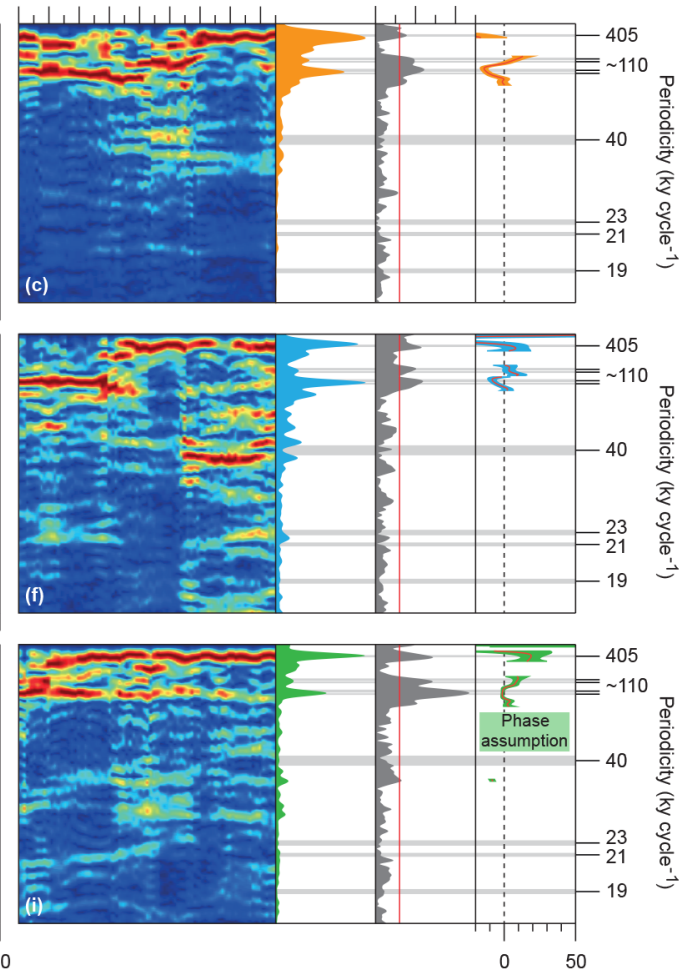

Lead $<$ phase $(\mathrm{ky})>$ lag

Figure 5. Implication of age models on time series analysis. (a-c) Time-evolutive FFT analysis of $\mathrm{CaCO}_{3}$ content on the initial magnetostratigraphic age model (i.e. a third-order polynomial), the $\mathrm{CaCO}_{3}$ content tuned age model, and the $\delta^{13} \mathrm{C}$ tuned age model, respectively. Panels (d-f) are as in $(\mathbf{a}-\mathbf{c})$ but for benthic foraminiferal $\delta^{18} \mathrm{O}$. Panels $(\mathbf{g}-\mathbf{i})$ are as in $(\mathbf{a}-\mathbf{c})$ but for benthic foraminiferal $\delta^{13} \mathrm{C}$. For all records, periodicities larger than $600 \mathrm{kyr}$ are removed using a notch filter. For panels (b) to (i): coherence with and phase relationships to eccentricity (La2011 solution) are depicted. All proxy data records were multiplied by -1 before computing the phase estimates.

foraminiferal $\delta^{13} \mathrm{C}$ are in-phase with eccentricity across the OMT (Fig. 7d). Approximately five $405 \mathrm{kyr}$ cycles are identified in the benthic foraminiferal $\delta^{13} \mathrm{C}$ record, which facilitate initial visual alignment to the same cycle in the eccentricity solution. Subsequently, we correlated the maxima and minima in the benthic foraminiferal $\delta^{13} \mathrm{C}$ record, as identified in Gaussian filters centred around the $\sim 110 \mathrm{kyr}$ cycle of this record on the initial magnetostratigraphic age model (Fig. 7a), to those identified in the filtered component of the eccentricity solution (Fig. 7d).

On the benthic foraminiferal $\delta^{13} \mathrm{C}$ tuned age model, our data span the interval between 22.1 and $24.2 \mathrm{Ma}$ (i.e. 2.1 Myr duration), resulting in an average time step of $3.4 \mathrm{kyr}$. LSRs generally range between 0.7 and $2.5 \mathrm{~cm} \mathrm{ky}^{-1}$, apart from an abrupt and short-lived increase across the OMT to $\sim 3.3 \mathrm{~cm} \mathrm{ky}^{-1}$. On the $\delta^{13} \mathrm{C}$ tuned age model, the $\mathrm{CaCO}_{3}$ record remains in anti-phase with respect to $\sim 110$ kyr eccentricity, but the benthic foraminiferal $\delta^{13} \mathrm{C}$ tuning results in an alternative alignment of $\mathrm{CaCO}_{3}$ cycles to eccentricity, which yields a $\sim 110 \mathrm{kyr}$ shorter duration of the record and causes the sudden increase in sedimentation rates across the OMT (Figs. 6 and 7). The evolutive analyses and power spectra are broadly consistent with the evolutive analyses from the $\mathrm{CaCO}_{3}$ tuned age model, with dominant $405 \mathrm{kyr}$ cyclicity in all three datasets, an increase in spectral power at $\sim 110 \mathrm{kyr}$ eccentricity cycles after the OMT, and intermittent expression of higher-frequency astronomical cycles (Fig. 5). On the $\delta^{13} \mathrm{C}$ tuned age model, all datasets exhibit a relatively stronger response at the $95 \mathrm{kyr}$ short eccentricity cycle than the $125 \mathrm{kyr}$ short eccentricity cycle in contrast to the $\mathrm{CaCO}_{3}$ tuned age model. In the late Oligocene, between $\sim 23.3$ and $23.8 \mathrm{Ma}$, strong $40 \mathrm{kyr}$ obliquity cycles are present in the benthic foraminiferal $\delta^{18} \mathrm{O}$ record on the $\delta^{13} \mathrm{C}$ tuned age model.

Cross-spectral analyses between the $\mathrm{CaCO}_{3}$ content, $\delta^{18} \mathrm{O}$, and $\delta^{13} \mathrm{C}$ records on the $\delta^{13} \mathrm{C}$ tuned age model and eccentricity indicate that all are significantly coherent at the 405, 125, and 95 kyr eccentricity cycles (Fig. 5). $\mathrm{CaCO}_{3}$ content leads eccentricity by $-24 \pm 18 \mathrm{kyr}$ at the $405 \mathrm{kyr}$ cycle and by $-7 \pm 3 \mathrm{kyr}$ at the $\sim 110 \mathrm{kyr}$ cycle. On the $\delta^{13} \mathrm{C}$ tuned age model, phase estimates of $\delta^{18} \mathrm{O}$ with respect to eccentricity 


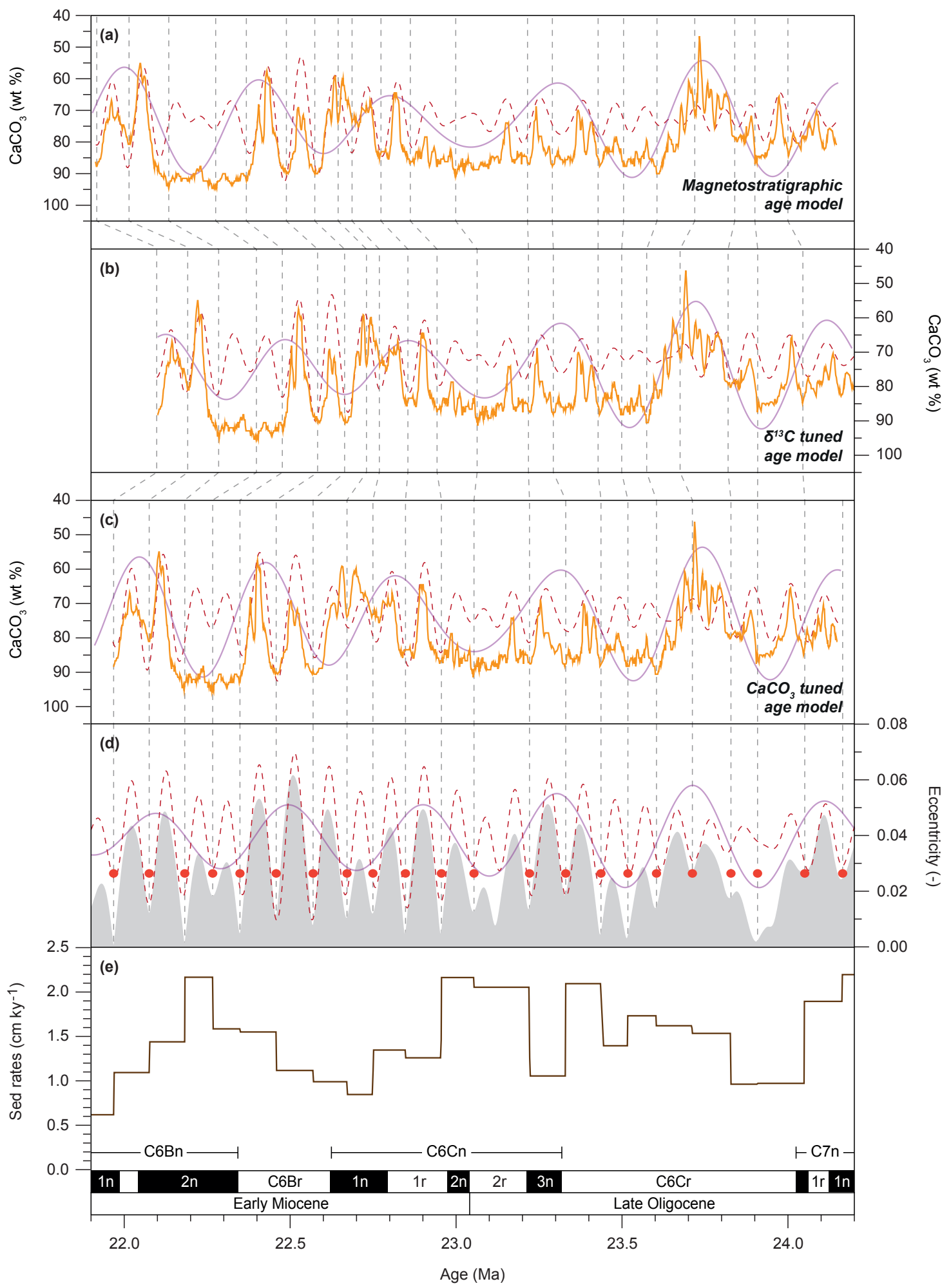

Figure 6. Site $\mathrm{U} 1334 \mathrm{CaCO}_{3}$ vs. age. (a) The $\mathrm{CaCO}_{3}$ dataset and 405 and $\sim 110 \mathrm{kyr}$ Gaussian filters plotted on (a) the magnetostratigraphic age model, (b) the $\delta^{13} \mathrm{C}$ tuned age model, and (c) the $\mathrm{CaCO}_{3}$ tuned age model. (d) Earth's orbital eccentricity solution is plotted in grey (Laskar et al., 2011a, b). Tie points are represented by red dots and dashed lines. Gaussian filters were calculated in AnalySeries (Paillard et al., 1996) with the following settings: $405 \mathrm{kyr}-\mathrm{f}: 2.5 \mathrm{bw}: 0.8, \sim 110 \mathrm{kyr}-\mathrm{f}: 10$, bw: 3 . (e) Sedimentation rates are calculated using the $\mathrm{CaCO}_{3}$ tuned age model. 


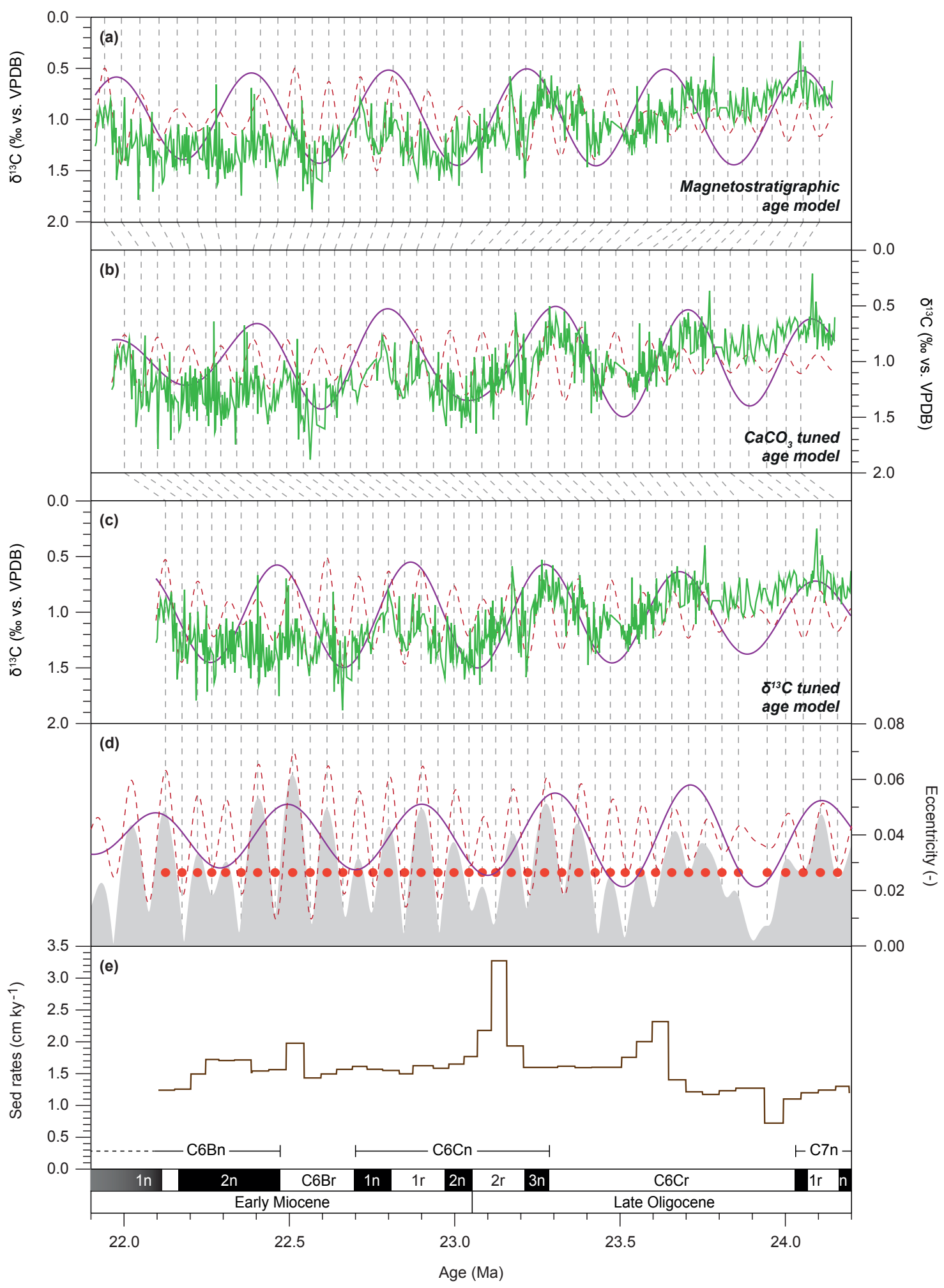

Figure 7. Site U1334 $\delta^{13} \mathrm{C}$ vs. age. The $\delta^{13} \mathrm{C}$ dataset and $405 \mathrm{kyr}$ and $\sim 110 \mathrm{kyr}$ Gaussian filters plotted on (a) the magnetostratigraphic age model, (b) the $\mathrm{CaCO}_{3}$ tuned age model, and (c) the $\delta^{13} \mathrm{C}$ tuned age model. (d) Earth's orbital eccentricity solution is plotted in grey (Laskar et al., 2011a, b). Tie points are represented by red dots and dashed lines. Gaussian filters were calculated in AnalySeries (Paillard et al., 1996) with the following settings: $405 \mathrm{kyr}-\mathrm{f}: 2.5 \mathrm{bw}: 0.8, \sim 110 \mathrm{kyr}-\mathrm{f}: 10$, bw: 3 . (e) Sedimentation rates are calculated using the $\delta^{13} \mathrm{C}$ tuned age model. 
show small leads of $-4 \pm 12 \mathrm{kyr}$ at the $405 \mathrm{kyr}$ cycle and of $-1 \pm 4 \mathrm{kyr}$ at the $\sim 110 \mathrm{kyr}$ cycle. Benthic foraminiferal $\delta^{13} \mathrm{C}$ lags eccentricity by $19 \pm 8 \mathrm{kyr}$ at the $405 \mathrm{kyr}$ cycle and by $3 \pm 2 \mathrm{kyr}$ at the $\sim 110 \mathrm{kyr}$ eccentricity cycle, which is congruent with the in-phase tuning assumption between benthic foraminiferal $\delta^{13} \mathrm{C}$ and eccentricity that is used in this age model.

\subsubsection{Age model comparison}

The final eccentricity tuned age models for the OMT time interval differ for two reasons. Firstly, there are 21 complete $\sim 110 \mathrm{kyr}$ cycles in the $\delta^{13} \mathrm{C}$ tuned age model and 22 in the $\mathrm{CaCO}_{3}$ content record. The tuned age models are largely consistent with each other during the late Oligocene and OMT interval. The base of chron C6Cn.2n, which marks the Oligocene-Miocene boundary, occurs within $10 \mathrm{kyr}$ on both age models. The two astronomically tuned age models diverge at $\sim 22.7 \mathrm{Ma}$, where the $\mathrm{CaCO}_{3}$ content has an additional $\sim 110 \mathrm{kyr}$ cycle on the initial magnetostratigraphic age model. A second factor contributing to the difference between the two astronomically tuned age models is the different phase relationships between the two proxy records and eccentricity (i.e. either $\mathrm{CaCO}_{3}$ is in-phase eccentricity or benthic foraminiferal $\delta^{13} \mathrm{C}$ ). These different phase assumptions that underpin the two tuned age models account for age differences up to $10 \%$ at all periodicities in the two records (Table 2 ) in addition to the $\sim 110 \mathrm{kyr}$ difference for the early Miocene interval of Site U1334 that results from the two different cyclostratigraphic interpretations. In turn, these interpretations are resultant from the initial phase assumptions. The longer lag time of $\delta^{13} \mathrm{C}$ with respect to eccentricity, in comparison with $\mathrm{CaCO}_{3}$, leads to older ages assigned to $\sim 110 \mathrm{kyr}$ cycles in the $\delta^{13} \mathrm{C}$ age model. This is particularly notable between 22.7 and $24.2 \mathrm{Ma}$, when the difference between the age models is accounted for only by the difference in phase.

\section{Spreading rates}

To independently test whether the $\mathrm{CaCO}_{3}$ tuned ages or the benthic foraminiferal $\delta^{13} \mathrm{C}$ tuned ages and their underlying phase assumption are most appropriate for tuning the deepmarine Oligocene-Miocene records from Site U1334, we assign the tuned magnetostratigraphic reversal ages from Site U1334 to those identified in an anomaly profile of tectonic plate pairs. We use the evolution through time of the spreading rates of these plate pairs as a control for our tuned age models (Wilson, 1993; Krijgsman et al., 1999). Rapid simultaneous fluctuations in the spreading rate of multiple plate pairs are highly unlikely and indicate errors in the tuned timescale. We propose using the astronomically tuned age model from Site U1334 that passes this test most successfully to provide ages for $\mathrm{C} 6 \mathrm{Bn} .1 \mathrm{n}(\mathrm{o})$ to $\mathrm{C} 7 \mathrm{n} .1 \mathrm{r}$ (o) and potentially revise those currently presented in the GTS2012.
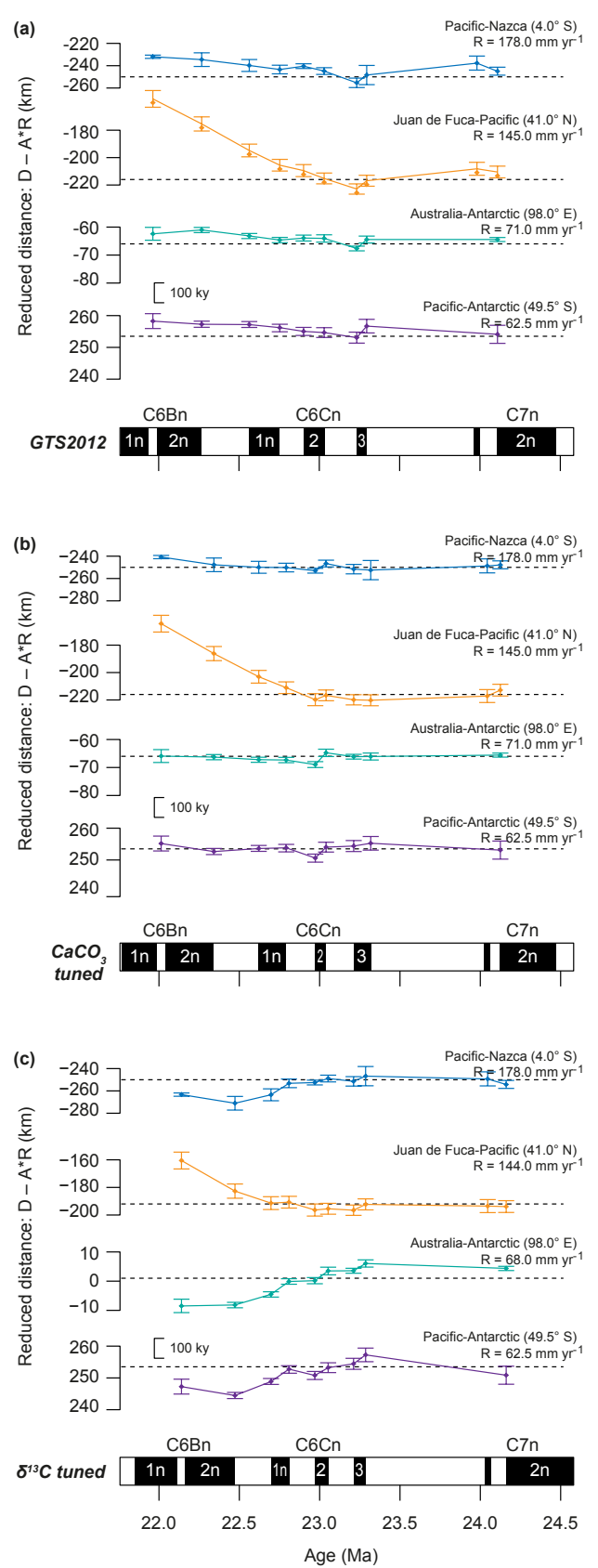

Figure 8. Plate-pair spreading rates based on different age models. Reduced-distance plots for the labelled plate pairs implied by (a) the GTS2012, (b) the $\mathrm{CaCO}_{3}$ tuned age model, and (c) the $\delta^{13} \mathrm{C}$ tuned age model. Reduced distance is the full spreading distance (D) minus the age (A) times the labelled spreading rate ( $R$; see $y$ axes). Distance scale is plotted inversely with spreading rate. This results in age errors that depart vertically from a straight line when spreading rates are constant. Inset scale bar shows the vertical offset resulting from a $100 \mathrm{kyr}$ change in a reversal age. Dashed horizontal lines are viewing aids to evaluate the prediction that constant spreading at the reduction rate $R$ will produce a horizontal line. Error bars are $95 \%$ confidence. The $\mathrm{CaCO}_{3}$-based age model (b) gives the simplest spreading-rate history and represents the preferred tuning option. 
Table 2. Comparison of tuning methods and phase relationships. List of astronomically dated Oligocene-Miocene spanning record. Tuning signal (i.e. lithological or climatic proxy records) and target curves (i.e. astronomical solutions) and phase relationships to the target curves are compared. Please note: not all records span the same time interval, and time average mid-phase estimates are given. A: Billups et al. (2004), B: Pälike et al. (2006a), C: Pälike et al. (2006b), D: Liebrand et al. (2016); for time-evolutive phase estimates of benthic foraminiferal $\delta^{18} \mathrm{O}$ with respect to eccentricity see Liebrand et al. (2017). E and F: this study.

\begin{tabular}{|c|c|c|c|c|c|c|c|c|c|}
\hline Site & Tuning signal & Tuning target & Age range & $\begin{array}{l}\operatorname{Lead}(-) / \\
\mathrm{Lag}(+) \\
405 \mathrm{kyr} \\
\mathrm{CaCO}_{3} \\
\text { content }\end{array}$ & $\begin{array}{l}\operatorname{Lead}(-) / \\
\operatorname{Lag}(+) \\
\sim 110 \mathrm{kyr} \\
\mathrm{CaCO}_{3} \\
\text { content }\end{array}$ & $\begin{array}{l}\operatorname{Lead}(-) / \\
\operatorname{Lag}(+) \\
405 \mathrm{kyr} \\
\delta^{18} \mathrm{O}\end{array}$ & $\begin{array}{l}\operatorname{Lead}(-) / \\
\operatorname{Lag}(+) \\
\sim 110 \mathrm{kyr} \\
\delta^{18} \mathrm{O}\end{array}$ & $\begin{array}{l}\text { Lead(-)/ } \\
\operatorname{Lag}(+) \\
405 \mathrm{kyr} \\
\delta^{13} \mathrm{C}\end{array}$ & $\begin{array}{l}\operatorname{Lead}(-) / \\
\operatorname{Lag}(+) \\
\sim 110 \mathrm{kyr} \\
\delta^{13} \mathrm{C}\end{array}$ \\
\hline A: 1090 & Benthic foram. $\delta^{18} \mathrm{O}$ & $\begin{array}{l}\text { E/O/P (mainly } \\
\text { obliquity) }\end{array}$ & $24-20 \mathrm{Ma}$ & - & - & In-phase & $+5 \mathrm{kyr}$ & $+25 \mathrm{kyr}$ & $+10 \mathrm{kyr}$ \\
\hline B: $926 / 929$ & $\mathrm{CaCO}_{3}$ content $^{\mathrm{a}}$ & $\begin{array}{l}\mathrm{E} / \mathrm{O} / \mathrm{P} \text { (mainly } \\
\text { obliquity) }\end{array}$ & $26-17 \mathrm{Ma}$ & - & - & $+10 \mathrm{kyr}$ & $+25 \mathrm{kyr}$ & $+35 \mathrm{kyr}$ & $+28 \mathrm{kyr}$ \\
\hline C: 1218 & Benthic foram. $\delta^{13} \mathrm{C}$ & $\begin{array}{l}\mathrm{E} / \mathrm{O} / \mathrm{P} \text { (mainly } \\
\text { eccentricity) }\end{array}$ & $34-22 \mathrm{Ma}$ & - & - & $+8 \mathrm{kyr}$ & $\sim$ In-phase & $+25 \mathrm{kyr}$ & $\sim$ In-phase \\
\hline D: 1264 & $\mathrm{CaCO}_{3}$ content $^{\mathrm{b}}$ & Eccentricity & $30-17 \mathrm{Ma}$ & $\begin{array}{l}\text { Unstable } \\
\text { phase }\end{array}$ & In-phase & $-14 \mathrm{kyr}$ & $+12 \mathrm{kyr}$ & $+36 \mathrm{kyr}$ & $+12 \mathrm{kyr}$ \\
\hline E: U1334 & $\mathrm{CaCO}_{3}$ content $^{\mathrm{c}}$ & Eccentricity & $24-22 \mathrm{Ma}$ & $+6 \mathrm{kyr}$ & In-phase & $+21 \mathrm{kyr}$ & $+9 \mathrm{kyr}$ & $+29 \mathrm{kyr}$ & $+9 \mathrm{kyr}$ \\
\hline F: U1334 & Benthic foram. $\delta^{13} \mathrm{C}$ & Eccentricity & $24-22 \mathrm{Ma}$ & $-24 \mathrm{kyr}$ & $-7 \mathrm{kyr}$ & $-4 \mathrm{kyr}$ & In-phase & $+19 \mathrm{kyr}$ & $\sim$ In-phase \\
\hline
\end{tabular}

a Magnetic susceptibility and colour reflectance.

b Natural logarithm of (X-ray fluorescence) Ca over Fe counts.

c Magnetic susceptibility.

On the $\mathrm{CaCO}_{3}$ tuned age model, the Australia-Antarctica, Pacific-Nazca, and Pacific-Antarctic plate pairs are all very close to a constant spreading rate (Fig. 8). The Juan de FucaPacific plate pair indicates a sudden decrease in spreading rate $\left(145\right.$ to $105 \mathrm{~mm} \mathrm{yr}^{-1}$ ) at $\sim 23 \mathrm{Ma}$, consistent with expectations (see the above Sect. 2.5; Wilson, 1988). In contrast, the synchronous changes for the Australia-Antarctica, Pacific-Nazca, and Pacific-Antarctic plate pairs in the $\delta^{13} \mathrm{C}$ tuned age model, especially the faster spreading rates $\sim$ 22.5-23.0 Ma implied by older ages for C6Bn, make this tuning option less plausible. Differences between the $\mathrm{CaCO}_{3}$ tuned age model for Site U1334 and GTS2012 are subtler. The longer duration of $\mathrm{C} 6 \mathrm{Cn} .3 \mathrm{n}$ in the $\mathrm{CaCO}_{3}$ tuned age model (106 vs. $62 \mathrm{kyr}$; Table 1) eliminates a brief and relatively small pulse of fast spreading implied by GTS2012, which is visible in Fig. 8a as positive slopes in age-distance during that chron. Over longer intervals, $\mathrm{CaCO}_{3}$ tuned ages remove a slight but synchronous rate slowdown that is also implied by GTS2012 and which starts at $\sim 23.2 \mathrm{Ma}$.

The $\mathrm{CaCO}_{3}$ tuned age model indicates a duration for C6Cn.2n of $67 \mathrm{kyr}$. This duration may be up to $\sim 40 \mathrm{kyr}$ too short, as is suggested by the relatively short-lasting increase in spreading rates during this chron (see the positive slopes in Fig. 8b). The spreading-distance error bars indicate that this age discrepancy is marginally significant, with no overlap in reduced distance for the boundaries of this chron for three of four plate pairs. Despite this small uncertainty in the duration for chron $\mathrm{C} 6 \mathrm{Cn} .2 \mathrm{n}$ on the $\mathrm{CaCO}_{3}$ tuned age model, the base of this chron appears in good agreement with spreading rates and thus suggests a slightly older age for the Oligocene-Miocene boundary of approximately 23.06 Ma. Furthermore, the polarity chron ages from the $\mathrm{CaCO}_{3}$ tuned ages are generally older by approximately $40 \mathrm{kyr}$ on average than those presented in the GTS2012 (Table 1). In both the $\mathrm{CaCO}_{3}$ content and $\delta^{13} \mathrm{C}$ record, the short interval around $\mathrm{C} 6 \mathrm{Cn} .2 \mathrm{n}$ is difficult to align to the eccentricity solution (Figs. 5 and 6) because $\mathrm{CaCO}_{3}$ content values are high with little variability, and benthic foraminiferal $\delta^{13} \mathrm{C}$ values correspond to the marked shift towards higher values at the Oligocene-Miocene carbon maximum (Hodell and Woodruff, 1994). The $83 \mathrm{kyr}$ duration of C6Cn.2n from the $\delta^{13} \mathrm{C}$ tuned age model is better supported by spreading rates than the $67 \mathrm{kyr}$ duration from the $\mathrm{CaCO}_{3}$ tuned age model, and the $118 \mathrm{kyr}$ duration in GTS2012 is even more consistent with constant spreading rates. If we extrapolate constant spreading rates across $\mathrm{C} 6 \mathrm{Cn} .2 \mathrm{n}$ using the $\mathrm{CaCO}_{3}$ tuned age for the base of $23.06 \mathrm{Ma}$, we obtain an age for the top of this normal polarity interval of $\sim 22.95 \mathrm{Ma}$ and a duration of 110 kyr. An important implication of the $\mathrm{CaCO}_{3}$ tuned ages is the delayed increase in spreading rates of the Juan de Fuca-Pacific plate pair. On the $\mathrm{CaCO}_{3}$ tuned age model this occurred approximately $200 \mathrm{kyr}$ later than those ages presented in the GTS2012 (i.e. during chron C6Cn.2n instead of C6Cn.3n; see Fig. 8). 


\section{Discussion}

\subsection{Evaluation of tuning signals}

Of the two astronomically tuned age models and GTS2012, the $\mathrm{CaCO}_{3}$ tuned age model is most consistent with the assumption of the least amount of changes in plate-pair spreading rates, which makes it the preferred astronomically tuned age model option for Site U1334 (Fig. 8). This agreement between plate-pair spreading-rate history and the $\mathrm{CaCO}_{3}$ tuned ages suggests that local and/or regional (i.e. lithological) tuning signals can produce more accurate age models in comparison with age models based on globally integrated isotope records. The latter data are known to produce significant lags relative to eccentricity as a result of highly non-linear feedback mechanisms (Laurin et al., 2017; Pälike et al., 2006b; Zeebe et al., 2017), a result that is confirmed by this study (Table 2). The independent evidence that we provide for using a lithological (proxy) record for the astronomical age calibration of marine sediments yields further support for similar astronomical tuning methods. Examples are the middle Miocene (Kochhann et al., 2016) and Eocene-Oligocene (Westerhold et al., 2015) records from the equatorial Pacific Ocean and the Oligocene-Miocene records from the South Atlantic Ocean (Liebrand et al., 2016). We note, however, that these records show variable ratios of productivity to dissolution as the main source of variance in the data. Future additional testing of phase uncertainties could include statistical approaches, such as Monte Carlo simulations (Khider et al., 2017).

\subsection{Implications for the carbon cycle}

Benthic foraminiferal $\delta^{13} \mathrm{C}$ variations in the open ocean are typically interpreted to reflect the ratio between global organic and inorganic carbon burial (Shackleton, 1977; Broecker, 1982; Diester-Haas et al., 2013; Mawbey and Lear, 2013). Astronomical forcing of organic carbon burial is typically expected in the precessional band because organic carbon burial, notably in the marine realm, depends on clay fluxes and thus hydrology (Berner et al., 1983). However, the residence time of carbon $(\sim 100 \mathrm{kyr})$ is so long (Broecker and Peng, 1982) that this energy is transferred into eccentricity bands (Pälike et al., 2006b; Ma et al., 2011; Laurin et al., 2017). Importantly, while the total marine carbon inventory is driven by ocean chemistry, the phase lag between eccentricity forcing and $\delta^{13} \mathrm{C}$ should primarily be a function of the residence time of carbon in the global exogenic carbon pool (Zeebe et al., 2017). Hypothetically, a change in total organic matter burial will only result in whole-ocean steady state when the $\delta^{13} \mathrm{C}$ of buried carbon equals that of the input (through rivers). Because the burial fluxes are small compared to the total carbon inventory, a pronounced time lag between eccentricity forcing and $\delta^{13} \mathrm{C}$ is expected (e.g. Zeebe et al., 2017).
Interestingly, the $\mathrm{CaCO}_{3}$ age model for Site U1334 suggests that the phase lag between the $405 \mathrm{kyr}$ cycle in the $\delta^{13} \mathrm{C}$ record and the eccentricity forcing increases across the OMT (see position of minima and maxima of the $405 \mathrm{kyr}$ filters of eccentricity and benthic foraminiferal $\delta^{13} \mathrm{C}$ in Fig. 7). In theory, an increase in the phase lag suggests an increase in the residence time of oceanic carbon, either through a rise in the total carbon inventory or a drop in the supply and burial of carbon (Zeebe et al., 2017). The lengthening of the phase lag of the $405 \mathrm{kyr}$ cycle coincides with a large shift in the benthic foraminiferal $\delta^{13} \mathrm{C}$ record across the OMT to more positive values, evidencing a structural relative increase in the supply of ${ }^{13} \mathrm{C}$-depleted carbon or a drop in the burial of ${ }^{13} \mathrm{C}$-enriched carbon. Reliable reconstructions of $\mathrm{CO}_{2}$ are rare across the OMT (www.p-co2.org) and the OMT does not seem associated with a large change in the depth of the Pacific calcite compensation depth (Pälike et al., 2012). Therefore, additional constraints on atmospheric $\mathrm{CO}_{2}$ concentrations and burial fluxes are required to better understand the climatic and oceanographic mechanisms associated with the increased phase lag (Egger et al., 2018).

\section{Conclusions}

We explore the application of $\mathrm{CaCO}_{3}$ content (estimated from magnetic susceptibility and shipboard coulometry) and benthic foraminiferal $\delta^{13} \mathrm{C}$ records as tuning signals for the OMT record at Site U1334 in the eastern equatorial Pacific. These two tunings highlight the importance of carefully considering the implications of tuning choices and assumptions when creating astronomical age models. Spreadingrate histories provide independent support for the $\mathrm{CaCO}_{3}$ tuned age model. This suggests that lithological signals respond more directly (though still non-linearly) to eccentricity than the stable isotope signals, for which we find support for a delayed response to astronomical climate forcing. Tuning to $\mathrm{CaCO}_{3}$ provides a valuable method to better understand the (lagged) response in benthic foraminiferal $\delta^{18} \mathrm{O}$ and $\delta^{13} \mathrm{C}$, which are widely used and reproducible proxies for the global climate-cryosphere system and (marine) carbon cycle. One important implication of the $\mathrm{CaCO}_{3}$ age model is that $405 \mathrm{kyr}$ cycle in benthic foraminiferal $\delta^{13} \mathrm{C}$ shows a distinct phase lag with respect to orbital eccentricity. Lastly, the $\mathrm{CaCO}_{3}$ age model for Site U1334 provides astronomically calibrated ages for C6Bn.1n to C7n.1r. The polarity chron ages from the $\mathrm{CaCO}_{3}$ tuned ages are generally older by approximately $40 \mathrm{kyr}$ on average than those presented in the GTS2012. We suggest that these updated early Miocene ages be incorporated in the next version of the geologic timescale.

Data availability. All data on the preferred $\mathrm{CaCO}_{3}$ tuned age model can be downloaded from www.pangaea.de or by following this link: https://doi.pangaea.de/10.1594/PANGAEA.885365 
Competing interests. The authors declare that they have no conflict of interest.

Acknowledgement. This research used samples provided by the Integrated Ocean Drilling Program (IODP) collected by the staff, crew, and scientists of IODP Expedition 320-321. We thank Dominika Kasjanuk, Arnold van Dijk, Maxim Krasnoperov, and Jan Drenth for laboratory assistance. Linda Hinnov kindly provided her evolutive analysis MATLAB script. We thank Christian Zeeden and an anonymous reviewer for their constructive reviews. We thank Marit-Solveig Seidenkrantz for the editorial handling. This research was supported by PalaeoClimate.Science (D. Liebrand), NWO grant 865.10.001 (L. J. Lourens), ERC grants 617462 (Earthsequencing, awarded to Heiko Pälike) and 259627 (A. Sluijs), NERC grant NE/G014817 (B. S. Wade), and a Marie Curie Career Integration Grant (number 293741) "ERAS". This work was carried out under the programme of the Netherlands Earth System Science Centre, which is financially supported by the Ministry of Education, Culture and Science.

Edited by: Marit-Solveig Seidenkrantz

Reviewed by: Christian Zeeden and one anonymous referee

\section{References}

Barckhausen, U., Ranero, C. R., Cande, S. C., Engels, M., and Weinrebe, W.: Birth of an intraoceanic spreading center, Geology, 36, 767-770, 2008.

Beddow, H. M., Liebrand, D., Sluijs, A., Wade, B. S., and Lourens, L. J.: Global change across the Oligocene-Miocene transition: High-resolution stable isotope records from IODP Site U1334 (equatorial Pacific Ocean), Paleoceanography, 31, 81-97, https://doi.org/10.1002/2015PA002820, 2016.

Berner, R. A., Lasaga, A. C., and Garrels, R. M.: The carbonatesilicate geochemical cycle and its effect on atmospheric carbon dioxide over the past 100 million years, Am. J. Sci., 283, 641683, https://doi.org/10.2475/ajs.283.7.641, 1983.

Billups, K., Pälike, H., Channell, J. E. T., Zachos, J. C., and Shackleton, N. J.: Astronomic calibration of the late Oligocene through early Miocene geomagnetic polarity time scale, Earth Planet. Sc. Lett., 224, 33-44, https://doi.org/10.1016/j.eps1.2004.05.004, 2004.

Broecker, W. S.: Glacial to interglacial changes in ocean chemistry, Prog. Oceanogr., 11, 151-197, 1982.

Broecker, W. S. and Peng, T.-H.: Tracers in the Sea, LamontDoherty Geological Observatory, Columbia University, Palisades, New York, 1982.

Cande, S. C. and Kent, D. V.: A new geomagnetic polarity time scale for the Late Cretaceous and Cenozoic, J. Geophys. Res., 97, 13917-13951, 1992.

Cande, S. C. and Stock, J. M.: Pacific-Antarctic-Australia motion and the formation of the Macquarie plate, J. Geophys. Int., 157, 399-414, 2004.

Channell, J. E. T., Ohneiser, C., Yamamoto, Y., and Kesler, M. S.: Oligocene-Miocene magnetic stratigraphy carried by biogenic magnetite at sites U1334 and U1335 (equatorial Pa- cific Ocean), Geochem. Geophy. Geosy., 14, 1525-2027, https://doi.org/10.1029/2012GC004429, 2013.

Croon, M. B., Cande, S. C., and Stock, J. M.: Revised PacificAntarctic plate motions and geophysics of the Menard Fracture Zone, Geochem. Geophy. Geosy., 9, Q07001, https://doi.org/10.1029/2008GC002019, 2008.

Diester-Haass, L., Billups, K., and Emeis, K.: Enhanced paleoproductivity across the Oligocene/Miocene boundary as evidenced by benthic foraminiferal accumulation rates, Palaeogeogr. Palaeocl., 302, 464-473, https://doi.org/10.1016/j.palaeo.2011.02.006, 2011.

Diester-Haass, L., Billups, K., Jacquemin, I., Emeis, K. C., Lefebvre, V., and François, L.: Paleoproductivity during the middle Miocene carbon isotope events: a data-model approach, Paleoceanography, 28, 334-346, 2013.

Egger, L. M., Sliwinska, K. K., van Peer, T. E., Liebrand, D., Lippert, P. C., Friedrich, O., Wilson, P. A., Norris, R. D. and Pross, J.: Magnetostratigraphically-calibrated dinoflagellate cyst bioevents for the uppermost Eocene to lowermost Miocene of the western North Atlantic (IODP Expedition 342, Paleogene Newfoundland sediment drifts), Rev. Palaeobot. Palynol., 234, 159185, 2016.

Egger, L. M., Bahr, A., Friedrich, O., Wilson, P. A., Norris, R. D., van Peer, T. E., Lippert, P. C., Liebrand, D., and Pross, J.: Sealevel and surface-water change in the western North Atlantic across the Oligocene-Miocene Transition: a palynological perspective from IODP Site U1406 (Newfoundland margin), Marine Micopaleo., 139, 57-71, 2018.

Herbert, T. D.: Reading orbital signals distorted by sedimentation: models and examples, orbital forcing and cyclic sequences, 483507, 1994.

Hilgen, F. J.: Astronomical Calibration of Gauss to Matuyama Sapropels in the Mediterranean and Implication for the Geomagnetic Polarity Time Scale, Earth Planet. Sci. Lett., 104, 226-244, 1991a.

Hilgen, F. J.: Extension of the Astronomically Calibrated (Polarity) Time Scale to the Miocene Pliocene Boundary, Earth Planet. Sci. Lett., 107, 349-368, 1991b.

Hilgen, F. J., Lourens, L. J., and Van Dam, J. A.: The neogene period, in: The Geologic Time Scale, Elsevier B.V., Amsterdam, 923-978, 2012.

Hodell, D. A. and Woodruff, F.: Variations in the strontium isotopic ratio of seawater during the Miocene: stratigraphic and geochemical implications, Paleoceanography, 9, 405-426, 1994.

Hodell, D. A., Charles, C. D., and Sierro, F. J.: Late Pleistocene evolution of the ocean's carbonate system, Earth Planet. Sc. Lett., 192, 109-124, 2001.

Holbourn, A., Kuhnt, W., Simo, J. T., and Li, Q.: Middle Miocene isotope stratigraphy and paleoceanographic evolution of the northwest and southwest Australian margins (Wombat Plateau and Great Australian Bight), Palaeogeogr. Palaeocl., 208, 1-22, 2004.

Holbourn, A., Kuhnt, W., Clemens, S., Prell, W., and Andersen, N.: Middle to late Miocene stepwise climate cooling: evidence from a high-resolution deep-water isotope curve spanning 8 million years, Paleoceanography, 28, 688-699, https://doi.org/10.1002/2013PA002538, 2013. 
Huybers, P. and Aharonson, O.: Orbital tuning, eccentricity, and the frequency modulation of climatic precession, Paleoceanography, 25, PA4228, https://doi.org/10.1029/2010PA001952, 2010.

Hüsing, S. K., Hilgen, F. J., Abdul Aziz, H., and Krijgsman, W.: Completing the Neogene geological time scale between 8.5 and 12.5 Ma, Earth Planet. Sc. Lett., 253, 340-358, 2007.

Khider, D., Ahn, S., Lisiecki, L. E., Lawrence, C. E., and Kienast, M.: The role of uncertainty in estimating lead/lag relationships in marine sedimentary archives: a case study from the tropical Pacific, Paleoceanography, 2016, PA003057, https://doi.org/10.1002/2016PA003057, 2017.

King, T.: Quantifying nonlinearity and geometry in time series of climate, Quaternary Sci. Rev., 15, 247-266, 1996.

Krijgsman, W., Hilgen, F. J., Raffi, I., Sierro, F. J., and Wilson, D. S.: Chronology, causes and progression of the Messinian salinity crisis, Nature, 400, 652-655, 1999.

Kochhann, K. G., Holbourn, A., Kuhnt, W., Channell, J. E., Lyle, M., Shackford, J. K., and Andersen, N.: Eccentricity pacing of eastern equatorial Pacific carbonate dissolution cycles during the Miocene Climatic Optimum, Paleoceanography, 31, 11761192, 2016.

Laskar, J., Robutel, P., Joutel, F., Gastineau, M., Correia, A. C. M., and Levrard, B.: A long-term numerical solution for the insolation quantities of the Earth, Astron. Astrophys., 428, 261-285, 2004.

Laskar, J., Fienga, A., Gastineau, M., and Manche, H.: La2010: A new orbital solution for the long term motion of the Earth, Astron. Astrophys., 532, 2011a.

Laskar, J., Gastineau, M., Delisle, J.-B., Farrés, A., and Fienga, A.: Strong chaos induced by close encounters with Ceres and Vesta, Astron. Astrophys., 532, 1-4, $2011 \mathrm{~b}$.

Laurin, J., Růžek, B., and Giorgioni, M.: Orbital signals in carbon isotopes: phase distortion as a signature of the carbon cycle, Paleoceanography, 2017, PA003143, https://doi.org/10.1002/2017PA003143, 2017.

Liebrand, D., Beddow, H. M., Lourens, L. J., Pälike, H., Raffi, I., Bohaty, S. M., Hilgen, F. J., Saes, M. J. M., Wilson, P. A., van Dijk, A. E., Hodell, D. A., Kroon., D., Huck, C. E., and Batenburg, S. J.: Cyclostratigraphy and eccentricity tuning of the early Oligocene through early Miocene (30.1-17.1 Ma): Cibicides mundulus stable oxygen and carbon isotope records from Walvis Ridge Site 1264, Earth Planet. Sc. Lett., 450, 392-405, 2016.

Liebrand, D., de Bakker, A. T. M., Beddow, H. M., Wilson, P. A., Bohaty, S. M., Ruessink, G., Pälike, H., Batenburg, S. J., Hilgen, F. J., Hodell, D. A., Huck, C. E., Kroon, D., Raffi, I., Saes, M. J. M., van Dijk, A. E., and Lourens, L. J.: Evolution of the early Antarctic ice ages, P. Natl. Acad. Sci. USA, 114, 38673872, 2017.

Littler, K., Röhl, U., Westerhold, T., and Zachos, J. C.: A highresolution benthic stable-isotope record for the South Atlantic: Implications for orbital-scale changes in Late Paleocene-Early Eocene climate and carbon cycling, Earth Planet. Sc. Lett., 401, 18-30, 2014.

Lonsdale, P.: Creation of the Cocos and Nazca plates by fission of the Farallon plate, Tectonophysics, 404, 237-264, https://doi.org/10.1016/j.tecto.2005.05.011, 2005.

Lourens, L. J., Hilgen, F. J., Shackleton, N. J., Laskar, J., and Wilson, D.: The neogene period, Chapt. 21, in: A Geologic Time
Scale 2004, edited by: Gradstein, F., Ogg, J. and Smith, A., Cambridge University Press, Cambridge, 409-440, 2004.

Ma, W., Tian, J., Li, Q., and Wang, P.: Simulation of long eccentricity $(400 \mathrm{kyr})$ cycle in ocean carbon reservoir during Miocene Climate Optimum: weathering and nutrient response to orbital change, Geophys. Res. Lett., 38, L10701, https://doi.org/10.1029/2011GL047680, 2011.

Mawbey, E. M. and Lear, C. H.: Carbon cycle feedbacks during the Oligocene-Miocene transient glaciation, Geology, 41, 963-966, 2013.

Paillard, D., Labeyrie, L., and Yiou, P.: Macintosh program performs time - series analysis, Eos Trans. AGU, 77, 379, https://doi.org/10.1029/96EO00259, 1996.

Pälike, H., Frazier, J., and Zachos, J. C.: Extended orbitally forced palaeoclimatic records from the equatorial Atlantic Ceara Rise, Quaternary Sci. Rev., 25, 3138-3149, 2006a.

Pälike, H., Norris, R. N., Herrle, J., Wilson, P. A., Coxall, H. K., Lear, C. H., Shackleton, N. J., Tripati, A. K., and Wade, B. S.: The heartbeat of the Oligocene climate system, Science, 314, 1894-1898, https://doi.org/10.1126/science.1133822, 2006b.

Pälike, H., Lyle, M. W., Nishi, H., Raffi, I., Gamage, K., Klaus, A., and the Expedition 320/321 Scientists: Proceedings of the Integrated Ocean Drilling Program, Volume 320/321, Integrated Ocean Drilling Program Management International, Inc., Tokyo, 2010.

Pälike, H., Lyle, M. W., Nishi, H., Raffi, I., Ridgewell, A., Gamage, K., Klaus, A., Acton, G., Anderson, L., Backman, J., Baldauf, J., Beltran, C., Bohaty, S. M., Bown, P., Busch, W., Channell, J. E. T., Chun, C. O. J., Delaney, M., Dewangan, P., Dunkley Jones, T., Edgar, K. M., Evans, H., Fitch, P., Foster, G. L., Gussone, N., Hasegawa, H., Hathorne, E.C., Hayashi, H., Herrle, J. O., Holbourn, A., Hovan, S., Hyeong, K., Iijima, K., Ito, T., Kamikuri, S., Kimoto, K., Kuroda, J., Leon-Rodriguez, L., Malinverno, A., Moore, T. C., Murphy, B. H., Murphy, D. P., Nakamura, H., Ogane, K., Ohneiser, C., Richter, C., Robinson, R., Rohling, E.J., Romero, O., Sawada, K., Scher, H., Schneider, L., Sluijs, A., Takata, H., Tian, J., Tsujimoto, A., Wade, B.S., Westerhold, T., Wilkens, R., Williams, T., Wilson, P.A., Yamamoto, Y., Yamamoto, S., Yamazaki, T., and Zeebe, R. E.: A Cenozoic record of the equatorial Pacific carbonate compensation depth. Nature, 488, 609-614, 2012.

Shackleton, N. J.: Carbon-13 in Uvigerina: Tropical rain forest history and the equatorial Pacific carbonate dissolution cycles, in: The Fate of Fossil Fuel $\mathrm{CO}_{2}$ in the Oceans, edited by: Andersen, N. R. and Malahoff, A., Plenum, New York, 401-427, 1977.

Shackleton, N. J., Hagelberg, T. K., and Crowhurst, S. J.: Evaluating the success of astronomical tuning: Pitfalls of using coherence as a criterion for assessing pre-Pleistocene timescales, Paleoceanography, 10, 693-697, https://doi.org/10.1029/95PA01454, 1995.

Shackleton, N. J., Crowhurst, S. J., Weedon, G. P., and Laskar, J.: Astronomical calibration of oligocene-miocene time, Philos. T. R. Soc. A, 357, 1907-1929, 1999.

Shackleton, N. J., Hall, M. A., Raffi, I., Tauxe, L., and Zachos, J. C.: Astronomical calibration age for the Oligocene/Miocene boundary, Geology, 28, 447-450, 2000.

Stewart, J. A., James, R. H., Anand, P., and Wilson, P. A.: Silicate Weathering and Carbon Cycle Controls on the Oligocene- 
Miocene Transition Glaciation, Paleoceanography, 32, 10701085, 2017.

Vandenberghe, N., Hilgen, F. J., and Speijer, R. P.: The paleogene period, in: The Geologic Time Scale 2012, Elsevier B.V., Amsterdam, 855-921, 2012.

van Peer, T. E., Xuan, C., Lippert, P. C., Liebrand, D., Agnini, C., and Wilson, P. A.: Extracting a Detailed Magnetostratigraphy From Weakly Magnetized, Oligocene to Early Miocene Sediment Drifts Recovered at IODP Site U1406 (Newfoundland Margin, Northwest Atlantic Ocean), Geochemistry Geophys. Geosyst., 18, 3910-3928, 2017a.

van Peer, T. E., Liebrand, D., Xuan, C., Lippert, P. C., Agnini, C., Blum, N., Blum, P., Bohaty, S. M., Bown, P. R., Greenop, R., Kordesch, W.E.C., Leonhardt, D., Friedrich, O., and Wilson, P. A.: Data report: revised composite depth scale and splice for IODP Site U1406, edited by: Norris, R. D., Wilson, P. A., Blum, P., and the Expedition 342 Scientists, in: Proceedings of the Integrated Ocean Drilling Program, 342: College Station, TX (Integrated Ocean Drilling Program), https://doi.org/10.2204/iodp.proc.342.202.2017, 2017 b.

Wade, B. S. and Palike, H.: Oligocene climate dynamics, Paleoceanography, 19, p. 16, 2004.

Westerhold, T., Röhl, U., Wilkens, R., Pälike, H., Lyle, M., Dunkley Jones, T., Bown, P., Moore, T., Kamikuri, S.-I., Acton, G., Ohneiser, C., Yamamoto, Y., Richter, C., Fitch, P., Scher, H., Liebrand, D., and Expedition 320/321 Scientists: Revised composite depth scales and integration of IODP Sites U1331-U1334 and ODP Sites 1218-1220, in: Proceedings of the Integrated Ocean Drilling Program, vol. 320/321, edited by: Pälike, H. et al., Integ. Ocean Drill. Progr. Manage. Int., College Station, TX, 2012a.

Westerhold, T., Röhl, U., and Laskar, J.: Time scale controversy: accurate orbital calibration of the early $\mathrm{Pa}-$ leogene, Geochem. Geophy. Geosy., 13, Q06015, https://doi.org/10.1029/2012GC004096, 2012b.
Westerhold, T., Röhl, U., Frederichs, T., Bohaty, S. M., and Zachos, J. C.: Astronomical calibration of the geological timescale: closing the middle Eocene gap, Clim. Past, 11, 1181-1195, https://doi.org/10.5194/cp-11-1181-2015, 2015.

Westerhold, T., Röhl, U., Frederichs, T., Agnini, C., Raffi, I., Zachos, J. C., and Wilkens, R. H.: Astronomical calibration of the Ypresian timescale: implications for seafloor spreading rates and the chaotic behavior of the solar system?, Clim. Past, 13, 11291152, https://doi.org/10.5194/cp-13-1129-2017, 2017.

Wilson, D. S.: Tectonic history of the Juan de Fuca ridge over the last 40 million years, J. Geophys. Res.-Sol. Ea., 93, 1186311876, 1988.

Wilson, D. S.: Confirmation of the astronomical calibration of the magnetic polarity time scale from rates of sea-floor spreading, Nature, 364, 788-790, 1993.

Zachos, J. C., Shackleton, N. J., Revenaugh, J. S., Pälike, H., and Flower, B. P.: Climate response to orbital forcing across the Oligocene - Miocene boundary, Science, 292, 274-278, 2001.

Zeebe, R. E., Westerhold, T., Littler, K., and Zachos, J. C.: Orbital forcing of the Paleocene and Eocene carbon cycle, Paleoceanography, 32, 440-465, https://doi.org/10.1002/2016PA003054, 2017.

Zeeden, C., Hilgen, F. J., Hüsing, S. K., and Lourens, L. J.: The Miocene astronomical time scale 9-12 Ma: new constraints on tidal dissipation and their implications for paleoclimatic investigations, Paleoceanography, 29, 296-307, 2014. 